\title{
Transport of anthropogenic and biomass burning aerosols from Europe to the Arctic during spring 2008
}

\author{
L. Marelle ${ }^{1,2}$, J.-C. Raut $^{1}$, J. L. Thomas ${ }^{1}$, K. S. Law ${ }^{1}$, B. Quennehen ${ }^{1}$, G. Ancellet ${ }^{1}$, J. Pelon ${ }^{1}$, A. Schwarzenboeck ${ }^{3}$, \\ and J. D. Fast ${ }^{4}$ \\ ${ }^{1}$ Sorbonne Universités, UPMC Univ. Paris 06; Université Versailles St-Quentin; CNRS/INSU, LATMOS-IPSL, Paris, France \\ ${ }^{2}$ TOTAL S.A/DS, Tour Coupole, 92078 Paris La Defense, France \\ ${ }^{3}$ Laboratoire de Météorologie Physique, UMR6016, Université Blaise Pascal, CNRS, Aubière, France \\ ${ }^{4}$ Pacific Northwest National Laboratory, Richland, Washington, USA \\ Correspondence to: L. Marelle (louis.marelle@latmos.ipsl.fr)
}

Received: 9 September 2014 - Published in Atmos. Chem. Phys. Discuss.: 17 November 2014

Revised: 16 March 2015 - Accepted: 20 March 2015 - Published: 10 April 2015

\begin{abstract}
During the POLARCAT-France airborne campaign in April 2008, pollution originating from anthropogenic and biomass burning emissions was measured in the European Arctic. We compare these aircraft measurements with simulations using the WRF-Chem model to investigate model representation of aerosols transported from Europe to the Arctic. Modeled $\mathrm{PM}_{2.5}$ is evaluated using European Monitoring and Evaluation Programme (EMEP) measurements in source regions and POLARCAT aircraft measurements in the Scandinavian Arctic. Total $\mathrm{PM}_{2.5}$ agrees well with the measurements, although the model overestimates nitrate and underestimates organic carbon in source regions. Using WRF-Chem in combination with the Lagrangian model FLEXPART-WRF, we find that during the campaign the research aircraft sampled two different types of European plumes: mixed anthropogenic and fire plumes from eastern Europe and Russia transported below $2 \mathrm{~km}$, and anthropogenic plumes from central Europe uplifted by warm conveyor belt circulations to $5-6 \mathrm{~km}$. Both modeled plume types had undergone significant wet scavenging (>50\% $\mathrm{PM}_{10}$ ) during transport. Modeled aerosol vertical distributions and optical properties below the aircraft are evaluated in the Arctic using airborne lidar measurements. Model results show that the pollution event transported aerosols into the Arctic $\left(>66.6^{\circ} \mathrm{N}\right)$ for a 4-day period. During this 4day period, biomass burning emissions have the strongest influence on concentrations between 2.5 and $3 \mathrm{~km}$ altitudes, while European anthropogenic emissions influence aerosols at both lower $(\sim 1.5 \mathrm{~km})$ and higher altitudes $(\sim 4.5 \mathrm{~km})$.
\end{abstract}

As a proportion of $\mathrm{PM}_{2.5}$, modeled black carbon and $\mathrm{SO}_{4}^{=}$ concentrations are more enhanced near the surface in anthropogenic plumes. The European plumes sampled during the POLARCAT-France campaign were transported over the region of springtime snow cover in northern Scandinavia, where they had a significant local atmospheric warming effect. We find that, during this transport event, the average modeled top-of-atmosphere (TOA) shortwave direct and semi-direct radiative effect (DSRE) north of $60^{\circ} \mathrm{N}$ over snow and ice-covered surfaces reaches $+0.58 \mathrm{~W} \mathrm{~m}^{-2}$, peaking at $+3.3 \mathrm{~W} \mathrm{~m}^{-2}$ at noon over Scandinavia and Finland.

\section{Introduction}

Arctic haze, which is present during winter and spring, is a well-known phenomenon that includes elevated concentrations of anthropogenic aerosols transported to the Arctic region (e.g., Rahn et al., 1977; Quinn et al., 2007). It was identified for the first time in the 1950s, when pilots experienced reduced visibility in the springtime North American Arctic (Greenaway, 1950; Mitchell, 1957). Further analysis showed that Arctic haze aerosols are mostly composed of sulfate, as well as organic matter, nitrate, sea salt, and black carbon (e.g., Quinn et al., 2002). Since local Arctic emissions are rather low, most air pollutants in the Arctic originate from transport from the mid-latitudes (Barrie, 1986). In late winter and early spring, Eurasian emissions can be efficiently transported at a low level in the Arctic (Rahn, 1981), when 
removal processes are particularly slow (Shaw, 1995; Garrett et al., 2011), causing elevated pollution concentrations in the lower troposphere. Surface aerosol concentrations in the Arctic are mostly influenced by European and west Asian emissions, while east Asian emissions have a larger influence in the upper troposphere (Fisher et al., 2011). Eurasian biomass burning emissions are thought to be major sources of Arctic pollution (Stohl, 2006; Warneke et al., 2010), but the magnitude of this contribution is still uncertain.

Aerosols play a key role in the climate system, through their absorption and scattering of solar radiation (direct effect, e.g., Haywood and Shine, 1995; Charlson et al., 1992), and through their impacts on cloud formation by modifying relative humidity and atmospheric stability (semi-direct effect, Ackerman et al., 2000) and by changing cloud properties, lifetime, and precipitation (indirect effects, Twomey, 1977; Albrecht, 1989). In the Arctic, several processes enhance the radiative impact of aerosols, including soot deposition on snow (Flanner et al., 2007), increased longwave emissivity in clouds in polluted conditions (Garret and Zhao, 2006), and the increased atmospheric heating effect of aerosols with weak absorbing properties over snow- or ice-covered surfaces (Pueschel and Kinne, 1995; Haywood and Shine, 1995). Modeling studies by Shindell and Faluvegi (2009) and Jacobson (2010) suggest that a good representation of aerosol composition and optical properties is critical to understand the Arctic energy budget. However, it is well known that aerosols amounts and properties in the Arctic are not well represented in global chemical transport models (Shindell et al., 2008). For example, Schwarz et al. (2010) showed that black carbon in global simulations does not agree well with observations in the Arctic and varies greatly between models. This discrepancy, especially at high altitudes, may be caused, in part, by insufficient rainout (e.g., Wang et al., 2013).

To improve our understanding about air pollution in the Arctic, several airborne campaigns were conducted in the Arctic region during the International Polar Year in 2008 in the framework of POLARCAT (POLar study using Aircraft, Remote sensing, surface measurements and models, of Climate, chemistry, Aerosols, and Transport; see Law et al., 2014). As part of the international project POLARCAT, the POLARCAT-France spring campaign took place from 30 March to 14 April 2008, based in Kiruna, Sweden $\left(67.8^{\circ} \mathrm{N}, 20.2^{\circ} \mathrm{E}\right)$. This campaign focused on Arctic cloud-aerosol interactions, satellite measurement validation, and transport of pollution plumes from mid-latitudes to the Arctic. During the campaign, several anthropogenic and biomass burning plumes originating in Europe and Asia were transported to the flight area and sampled during flights in April 2008 (de Villiers et al., 2010; Quennehen et al., 2012). De Villiers et al. (2010) analyzed the optical properties of aerosol plumes measured by airborne and spaceborne lidar, and Quennehen et al. (2012) studied aerosol ageing from size distributions measured in situ during the POLARCAT-
France spring campaign. These studies pointed out the need for modeling to quantify the influence of different processes and sources on aerosols observed during the campaign.

The present study aims to improve our understanding about Arctic aerosol originating from Europe. In particular, we investigate the role of anthropogenic and biomass burning sources, transport pathways, aerosol ageing, and processes controlling the vertical distribution of aerosol plumes transported to the European Arctic in spring, and how they impact the aerosol burden and the aerosol radiative effect in this region. To achieve this objective, measurements from the POLARCAT-France airborne campaign in the Scandinavian Arctic in April 2008 are analyzed in combination with simulations using the regional WRF-Chem model to investigate cases of aerosol transport from Europe to the Arctic. In Sect. 2, we describe the methods used in our study, including a description of the POLARCAT-France spring airborne aerosols measurements, and the European Monitoring and Evaluation Programme (EMEP) ground-based aerosol measurements used to validate the model over European source regions. Section 2 also includes an overview of the modeling tools employed, WRF-Chem and FLEXPART-WRF, and describes the simulations performed in this study. In Sect. 3, we present the synoptic-scale meteorological conditions over Europe during the campaign, and how these conditions impacted long-range aerosol transport from Europe to the Arctic. In Sect. 4, the performance of the WRF-Chem simulation is evaluated using POLARCAT-France spring meteorological measurements and ground-based aerosol measurements in source regions. In Sect. 5, modeled aerosol physical and optical properties are compared to POLARCAT-France spring airborne in situ and lidar measurements. We also investigate in Sect. 5 the sources of aerosols observed during the campaign. The results are used in Sect. 6 to evaluate the regional impact of this transport event in terms of aerosols burden and direct radiative effects.

\section{Methods}

\subsection{POLARCAT-France spring campaign airborne measurements}

During the POLARCAT-France campaign, the French ATR42 research aircraft payload included two instruments to measure the particle size distribution: a scanning mobility particle sizer (SMPS, size range of 20 to $467 \mathrm{~nm}, 88$ channels, $140 \mathrm{~s}$ resolution) and a GRIMM optical particle counter (OPC, size range of 0.1 to $2 \mu \mathrm{m}$, eight channels, $1 \mathrm{~s}$ resolution). For the full-size distributions $(20 \mathrm{~nm}$ to $2 \mu \mathrm{m})$, data from the two instruments are combined as described in Quennehen et al. (2012). The ATR-42 was equipped with a counterflow virtual impactor (CVI) inlet (Schwarzenboeck et al., 2000) to sample aerosol particles and cloud droplets. In clouds, the CVI inlet was activated to remove interstitial 
aerosols and study cloud droplets only. Therefore, aerosol size distributions are only available out of clouds. However, clouds mostly impacted in situ measurements at lower altitudes $(<2 \mathrm{~km})$ and data are available for most periods of interest for modeling long-range transport of aerosols to the region (SMPS: 158 data points, $98 \%$ coverage above $1.5 \mathrm{~km}$; GRIMM: 22013 data points, $88 \%$ coverage above $1.5 \mathrm{~km}) . \mathrm{PM}_{2.5}$ concentrations along the flight track are estimated by integrating the size distributions ( $20 \mathrm{~nm}$ to $2 \mu \mathrm{m}$ ), assuming that all particles are spherical and have a density of $1700 \mathrm{~kg} \mathrm{~m}^{-3}$ (Quennehen et al., 2011). The contribution of particles in the $2-2.5 \mu \mathrm{m}$ diameter range to $\mathrm{PM}_{2.5}$ is missing from this estimation. However, we determine that it is negligible because $94 \%$ of the measured $20 \mathrm{~nm}$ to $2 \mu \mathrm{m}$ mass distribution in the POLARCAT-France data set is located in the lower size range of $20 \mathrm{~nm}$ to $1.6 \mu \mathrm{m}$, and because large particles are unlikely to be transported over long distances.

During the campaign, airborne aerosol lidar profiles were measured below or above the aircraft by the LNG instrument (lidar LEANDRE Nouvelle Génération) (Flamant and Pelon, 1996; de Villiers et al., 2010; Ancellet, 2014). Specifically, the LNG instrument measured aerosol optical properties at two wavelengths (532 and $1064 \mathrm{~nm}$ ) providing information about the location of aerosol layers vertically (in our case below the aircraft). The vertical resolution of the data presented is $30 \mathrm{~m}$ (four-point average) and the horizontal resolution is $450 \mathrm{~m}$ (average of 100 lidar profiles). In this work, we use the LNG measurements to study the spatial structure of aerosol layers below the aircraft and to analyze the representation of these aerosol layers in regional chemical transport modeling. For this purpose, we use the LNG measurements to calculate the pseudo-backscatter ratio (PBR), defined as the ratio of the measured lidar total attenuated backscatter (including Rayleigh and aerosol contributions) to simulated molecular backscatter at a certain wavelength. The uncertainty for this ratio is estimated to be $10 \%$ for the $532 \mathrm{~nm}$ channel and $20 \%$ for the $1064 \mathrm{~nm}$ channel by de Villiers et al. (2010). For this reason, we only use the $532 \mathrm{~nm}$ PBR in this study. In moderately polluted conditions (as observed during the POLARCAT-France spring campaign), the PBR is close to the true backscatter ratio, defined as $R_{T}=\frac{\left(\beta_{\mathrm{A}}+\beta_{\mathrm{M}}\right)}{\beta_{\mathrm{M}}}$, where $\beta_{\mathrm{A}}$ is the aerosol backscatter coefficient and $\beta_{\mathrm{M}}$ is the molecular backscatter coefficient, noting that the true backscatter ratio is equal to 1 in clear sky conditions, and is greater than 1 in aerosol layers. Several aerosol plumes were sampled in situ and measured by lidar during three flights on 9,10 , and 11 April 2008. The associated flight tracks, over northern Norway and the Norwegian Sea/Barents Sea region, are represented in Fig. 1.

\subsection{EMEP ground-based measurements}

The EMEP network of ground-based measurements includes both aerosol $\mathrm{PM}_{2.5}$ mass and aerosol chemical composition (available online from the EMEP database - http://www.nilu.

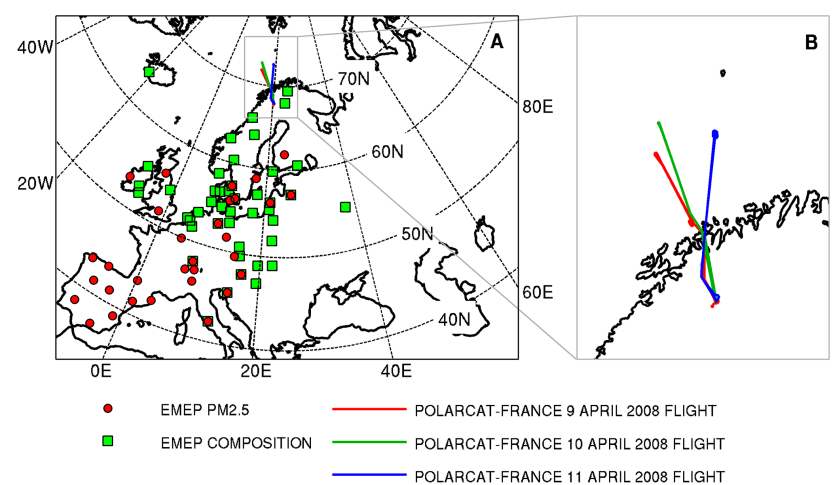

Figure 1. (a) WRF-Chem domain including the location of groundbased EMEP measurement stations used for this study. Stations measuring $\mathrm{PM}_{2.5}$ are marked by red circles, and stations measuring aerosol composition are marked by green squares. Stations with both measurements are indicated with both symbols. The POLARCAT-France spring flight tracks are shown in red, green, and blue, with a close up over the flight region shown in (b).

no/projects/ccc/). Stations from the EMEP network are typically outside of urban centers and are intended to represent air free of recent pollution sources. We use the EMEP measurements of $\mathrm{PM}_{2.5}$, as well as chemical composition in $\mathrm{SO}_{4}^{=}$, organic carbon (OC), black carbon (BC), $\mathrm{NH}_{4}^{+}$, and $\mathrm{NO}_{3}^{-}$to evaluate model aerosols from 1 April to 11 April 2008, using data from stations with either daily or hourly data. Stations are excluded if they have less than $75 \%$ data coverage during this period, and $\mathrm{OC}$ and $\mathrm{BC}$ measurements are excluded because of the lack of spatial coverage of measurements (four stations for $\mathrm{BC}$, five for OC). The locations of stations used for model comparison are shown in Fig. 1, including stations that measure $\mathrm{PM}_{2.5}$ (33 stations) and stations that measure aerosol mass of $\mathrm{SO}_{4}^{=}, \mathrm{NH}_{4}^{+}$, and $\mathrm{NO}_{3}^{-}(34,31$, and 28 stations, respectively). The average data coverage for selected stations is $98 \%$.

\subsection{Model calculations: WRF-Chem and FLEXPART-WRF}

\subsubsection{WRF-Chem}

Regional chemical transport model simulations are performed with the version 3.5.1 of the WRF-Chem (Weather Research and Forecasting, including Chemistry) model to provide further insight into the POLARCAT-France spring aerosol measurements. WRF-Chem is a fully coupled, online meteorological and chemical transport mesoscale model (Grell et al., 2005; Fast et al., 2006). It has been successfully used in previous studies focused on the Arctic region (Sessions et al., 2011; Thomas et al., 2013) and to analyze airborne aerosols measurements (e.g., Fast et al., 2012). The model setup, including the representation of the planetary boundary layer (PBL), surface, radiative properties, con- 
Table 1. Parameterizations and options used for the WRF-Chem simulations.

\begin{tabular}{ll}
\hline Atmospheric process & WRF-Chem option \\
\hline Planetary boundary layer & MYJ (Janjic, 1994) \\
Surface layer & Monin-Obukhov Janjic Eta scheme (Janjic, 1994) \\
Land surface & Unified Noah land-surface model (Chen and Dudhia, 2001) \\
Microphysics & Morrison (Morrison, et al., 2009) \\
SW radiation & Goddard (Chou and Suarez, 1999) \\
LW radiation & RRTM (Mlawer et al., 1997) \\
Photolysis & Fast-J (Wild et al., 2000) \\
Cumulus parameterization & Grell-3 (Grell and Devenyi, 2002) \\
Gas-phase chemistry & CBM-Z (Zaveri and Peters, 1999) \\
Aerosol model & MOSAIC eight bins (Zaveri et al., 2008) \\
\hline
\end{tabular}

vection, microphysics, gas-phase chemistry, and aerosols, is shown in Table 1. Specifically, gas-phase reactions were simulated with the CBM-Z mechanism (Carbon Bond Mechanism, version Z, Zaveri and Peters, 1999) and aerosols are represented using the eight-bin sectional aerosol model MOSAIC (Model for Simulating Aerosol Interactions and Chemistry, Zaveri et al., 2008). MOSAIC aerosol processes include nucleation, evaporation, coagulation, condensation, dry deposition, and aerosol/cloud interactions, including aerosol activation as cloud condensation nuclei, cloud chemistry, and within- and below-cloud wet scavenging. Eight bins represent the size distribution of each aerosol species between $39 \mathrm{~nm}$ and $10 \mu \mathrm{m}$. Interstitial and cloud-borne aerosol particles are treated explicitly, and modeled aerosols can be activated or re-suspended depending on saturation, particle size, and aerosol composition. Aerosol activation changes cloud droplet number concentrations in the Morrison microphysics scheme, which is linked with the Goddard shortwave radiative scheme. Aerosol activation also affects cloud lifetime by influencing precipitation. Aqueous chemistry in clouds is based on Fahey and Pandis (2001), and includes oxidation of $\mathrm{S}(\mathrm{IV})$ by $\mathrm{H}_{2} \mathrm{O}_{2}, \mathrm{O}_{3}$, and other radicals, as well as nonreactive uptake of $\mathrm{NH}_{3}, \mathrm{HNO}_{3}, \mathrm{HCl}$, and other trace gases. Nucleation is based on Wexler et al. (1994). The CBM-ZMOSAIC eight-bin scheme is not coupled to a secondary organic aerosol (SOA) scheme in our version of WRF-Chem (3.5.1). According to Bessagnet et al. (2008), 75-95\% of annually averaged SOA in Europe is associated with biogenic sources. However, biogenic VOC (volatile organic compounds) emissions are relatively low in Europe during the months of March and April (Karl et al., 2009). In addition, Bessagnet et al. (2008) point out that SOA concentrations are much lower in northern Europe than in other European regions. For all of these reasons, and since current SOA mechanisms are highly uncertain (e.g., Hodzic et al., 2010; Gustafson et al., 2011), the present simulations do not include SOA formation. However, we note that Frossard et al. (2011) determined that SOA formation contributed in part to the organic aerosol fraction in the Scandinavian marine boundary layer during the period of the POLARCAT-
France flights (April 2008), and that our simulations cannot reproduce this contribution. MOSAIC considers aerosols as internally mixed in each bin, and in our simulations optical properties are calculated using volume averaging.

The simulation domain, focused on the POLARCATFrance spring flights, is shown in Fig. 1 and covers Europe north of $40^{\circ} \mathrm{N}$ and west of $70^{\circ} \mathrm{E}$. The spatial resolution is $30 \mathrm{~km} \times 30 \mathrm{~km}$ horizontally, with 50 vertical levels up to $50 \mathrm{hPa}$. Anthropogenic emissions were taken from the Hemispheric Transport of Air Pollution version 2 (HTAPv2) $0.1^{\circ} \times 0.1^{\circ}$ inventory (http://edgar.jrc.ec.europa.eu/htap_v2/ index.php?SECURE=123). HTAP VOCs are given as a bulk VOC mass, and are distributed into CBM-Z emission categories assuming the speciation of UK VOCs determined by Murrels et al. (2010). Time profiles are applied to anthropogenic emissions to account for the daily and weekly cycle of each emission sector (van der Gon et al., 2011). Fire emissions are from the FINN v1 inventory (Wiedinmyer et al., 2006, 2011), and are injected at altitude by an online plume rise model described in Freitas et al. (2007). Figure 2 shows black carbon (BC), organic carbon (OC), and sulfur oxides $\left(\mathrm{SO}_{\mathrm{x}}\right)$ emissions during our simulation, from both anthropogenic sources (panels a, b, and c) and biomass burning sources (panels $\mathrm{d}$, e, and $\mathrm{f}$ ). In-domain biomass burning emission totals are $13 \mathrm{kt}$ for $\mathrm{SO}_{\mathrm{x}}, 12 \mathrm{kt}$ for $\mathrm{BC}$, and $75 \mathrm{kt}$ for OC. For anthropogenic emissions, in-domain emission totals from HTAPv2 are $575 \mathrm{kt}$ for $\mathrm{SO}_{\mathrm{x}}, 21 \mathrm{kt}$ for $\mathrm{BC}$, and $46 \mathrm{kt}$ for OC. Anthropogenic emissions are stronger in western and central Europe, especially in Poland and Slovakia. Biomass burning emissions are located in the eastern part of the domain because of intense agricultural fires in Ukraine, Russia and Kazakhstan during early April 2008 (Warneke et al., 2009). Biogenic emissions are calculated online in WRFChem by the model MEGAN (Guenther et al., 2006). Finally, sea salt aerosol emissions are calculated online, while mineral dust emissions are not included.

Boundary and initial meteorological conditions in the simulation are given by the global NCEP Final Analysis (FNL), and WRF-Chem temperature, humidity, and winds are nudged every $6 \mathrm{~h}$ to the reanalysis above the atmo- 
ANTHRO. EMISSIONS
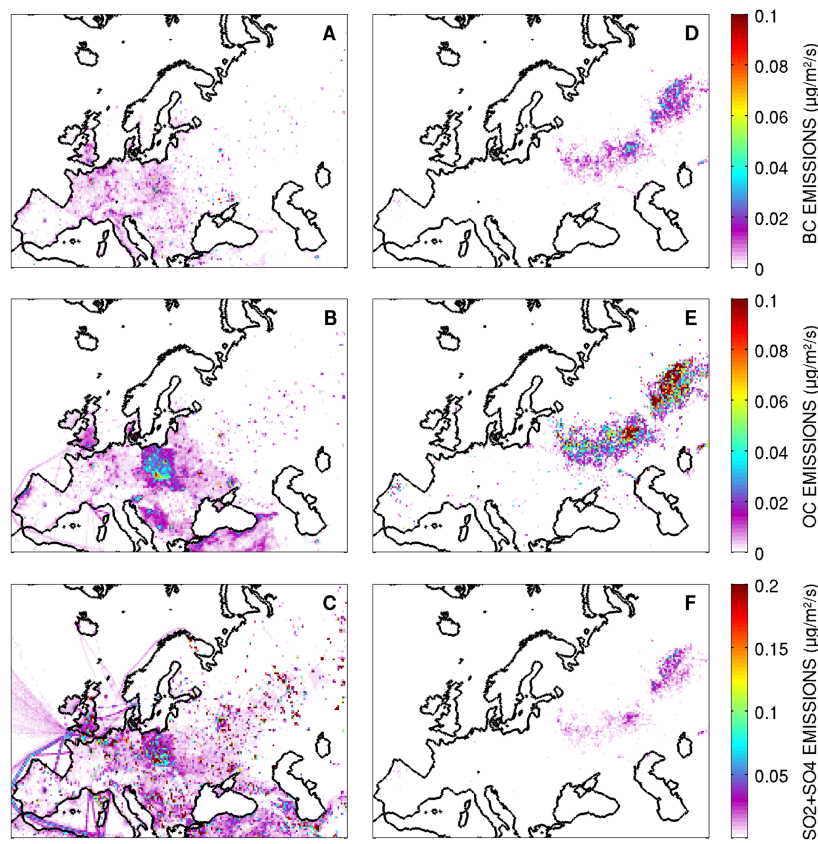

Figure 2. Averaged emissions within the model domain during the simulation period (1 April 2008-12 April 2008) due to anthropogenic activities (HTAP v2) and biomass burning (FINN v1). Anthropogenic $\mathrm{BC}, \mathrm{OC}$, and $\mathrm{SO}_{2}+\mathrm{SO}_{4}$ emissions are shown in (a-c) and biomass burning $\mathrm{BC}, \mathrm{OC}$, and $\mathrm{SO}_{2}+\mathrm{SO}_{4}$ emissions are shown in $(\mathbf{d}-\mathbf{f})$.

spheric boundary layer. Trace gases and aerosol initial and boundary conditions (updated every $6 \mathrm{~h}$ ) are taken from the global chemical transport model MOZART-4 (Emmons et al., 2010).

WRF-Chem simulations include a control run (CTL) from 00:00 UTC 1 April to 00:00 UTC 12 April using the model and emissions as described above. We also perform four sensitivity simulations for the same period to investigate the sources, processes along transport, and regional impacts of aerosols sampled during POLARCAT: (1) removing the HTAPv2 emissions (NOANTHRO), (2) without biomass burning emissions (NOFIRES), (3) a simulation with wet scavenging turned off (NOWETSCAV), and (4) a simulation with the aerosol direct interaction with shortwave radiation disabled, thus switching off the direct and semidirect aerosol effects (NODIRECT). The NOANTHRO and NOFIRES simulations are used in Sect. 5.1 to estimate the contribution of European anthropogenic and biomass burning emissions to Arctic aerosols measured during POLARCAT. The NOWETSCAV simulation allows us to quantify in Sect. 5.2 the magnitude of the wet scavenging of aerosols during their transport from Europe to the Arctic. The NODIRECT simulation is used in Sect. 6 to estimate the direct and semi-direct shortwave radiative effect (DSRE) of aerosols associated with this transport event.
To compare simulations with airborne lidar measurements, modeled backscatter ratio profiles at the plane position are calculated by using the aerosol backscattering coefficient at $400 \mathrm{~nm}$ simulated by WRF-Chem. This coefficient is computed within WRF-Chem from the method of Toon and Ackerman (1981), using a bulk, volume-averaged, refractive index derived from the modeled size distribution (Bond et al., 2006). The backscattering coefficient is then estimated at $532 \mathrm{~nm}$ by using the simulated Angström exponent, and the effect of aerosol transmission is ignored because aerosol optical depths (AODs) of observed layers were low $(<4 \%)$ during POLARCAT-France (de Villiers et al., 2010). The backscatter ratio is calculated following the definition in Sect. 2.1, where the molecular backscattering is estimated by an empirical formulation of the Rayleigh scattering (Nicolet, 1984) using meteorological profiles from the CTL simulation.

\subsubsection{FLEXPART-WRF}

We also use FLEXPART-WRF, a Lagrangian particle dispersion model (Brioude et al., 2013) adapted from the model FLEXPART (Stohl et al., 2005), to study air mass origins and transport processes using WRF meteorological forecasts. In this study, we use FLEXPART-WRF in backward mode to study the origin and transport pathways of plumes measured during the POLARCAT-France spring campaign, and to provide insight into the WRF-Chem representation of aerosols. The meteorological fields from the WRF-Chem simulation CTL described in 3.1 are used as input. Every minute, 10000 particles are released along the aircraft flight tracks in a volume $10 \mathrm{~km} \times 10 \mathrm{~km}$ (horizontally) and $400 \mathrm{~m}$ (vertically). Each of the simulations is run backwards for 7 days to track the air mass origin over the source regions of interest (transport times are typically less than 7 days). Specifically, we use FLEXPART-WRF potential emission sensitivity (PES) to study source-receptor relationships for air measured by the ATR-42 as part of the POLARCAT-France spring flights.

\section{Meteorological context during the spring POLARCAT-France campaign}

Long-range transport of aerosol from Europe to the Arctic is usually associated with specific synoptic meteorological conditions over Europe, causing large-scale meridional transport (e.g., Iversen and Joranger, 1985). In order to investigate the origin and transport of aerosols measured during the POLARCAT-France spring campaign, the synoptic meteorological conditions during the campaign as represented by WRF-Chem are shown in Fig. 3. Specifically, WRFChem simulated geopotential height contours and wind arrows $(700 \mathrm{hPa})$ are shown from 6 to 11 April 2008. A similar figure showing wind speed at $700 \mathrm{hPa}$ instead of geopotential height is shown in Fig. S1 in the Supplement. Low 

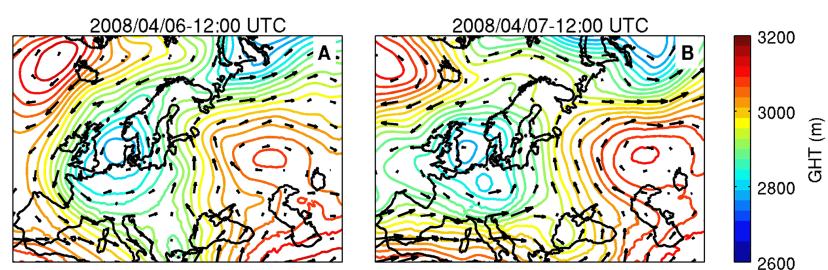

2008/04/08-12:00 UTC

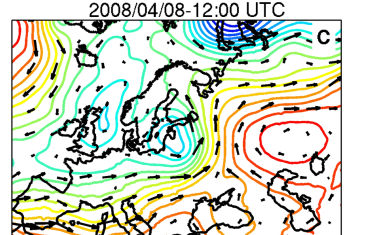

2008/04/09-12:00 UTC

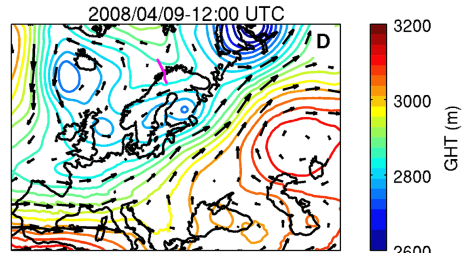

2008/04/10-12:00 UTC

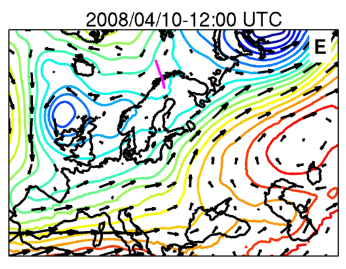

$\rightarrow \mathrm{V}=30 \mathrm{~m} / \mathrm{s}$
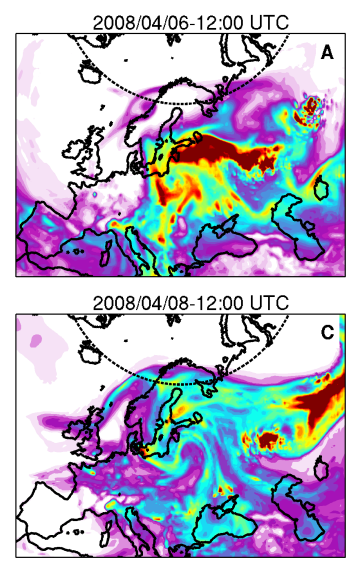

2008/04/10-12:00 UTC
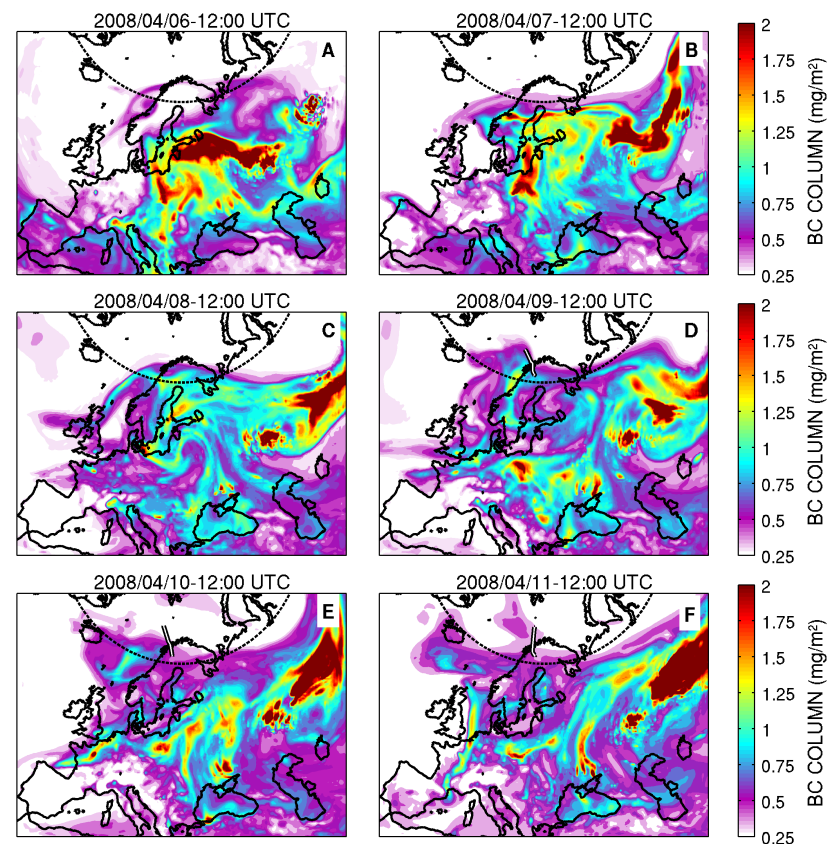

2008/04/11-12:00 UTC
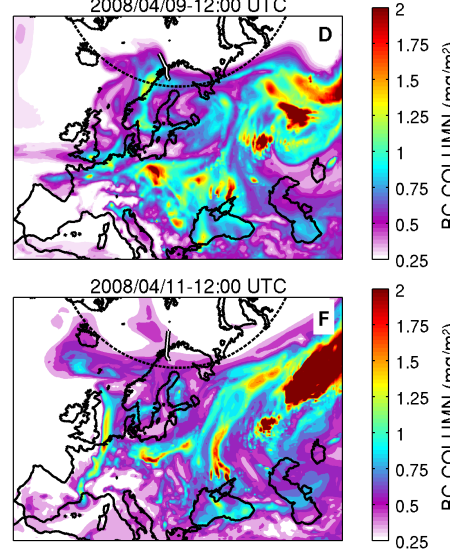

Figure 4. Simulated BC column on 6-11 April 2008 (12:00 UTC). POLARCAT-France flight tracks are indicated in white, with a black border.

slowly transporting the polluted European air back to lower latitudes. On 10-11 April, pollution (represented as elevated $\mathrm{BC}$ ) can be seen entering the simulation domain from the northern boundary over Svalbard (in our simulations via the MOZART-4 boundary conditions), and crossing the POLARCAT flight track on 11 April. This last polluted air mass is not the focus of the present study and has been identified as a mixed anthropogenic and biomass burning plume originating from northeast Asia. It has already been studied in detail by de Villiers et al. (2010) and Quennehen et al. (2012).

\section{Model validation}

Results from WRF-Chem are compared to POLARCATFrance $1 \mathrm{~s}$ resolution measurements of temperature, relative humidity, wind speed, and wind direction (CTL simulation) for the POLARCAT-France flights included in our study. This comparison is presented in Fig. 5. Modeled and measured quantities are in good agreement with the exception of fine-scale features that are not reproduced by the model due to the horizontal grid spacing $(30 \mathrm{~km})$. In particular, we note that relative humidity (RH) is well reproduced by the model $\left(R^{2}>0.88\right)$. Pilinis et al. (1995) showed that $\mathrm{RH}$, through aerosol water uptake, is a key parameter for modeling aerosol optical properties. The main discrepancies are between the measured and modeled wind speeds on 10 April 2008, when high winds were observed below $1 \mathrm{~km}$ (middle portion of the flight) over the Norwegian Sea. However, discrepancies between modeled and measured wind speeds in the marine 

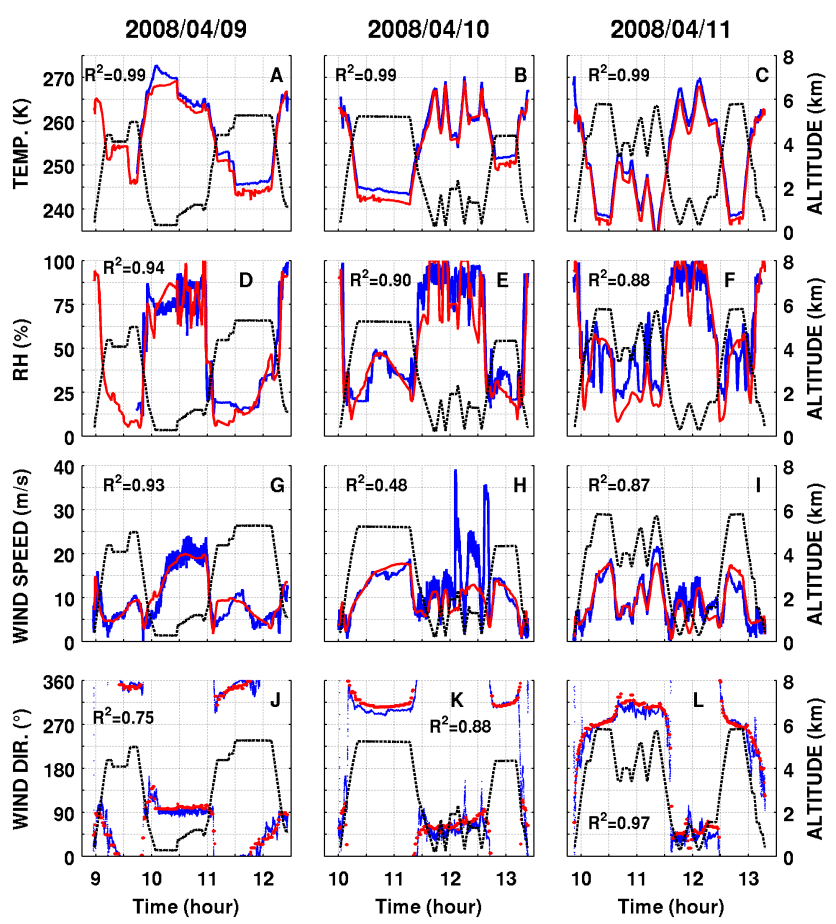

MODEL

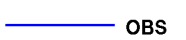

ALTITUDE

Figure 5. Time series of modeled (red) and measured (blue) (ac) temperature, $(\mathbf{d}-\mathbf{f})$ relative humidity, $(\mathbf{g}-\mathbf{i})$ wind speed, and $(\mathbf{j}-$ l) wind direction extracted along the POLARCAT-France flight tracks. The corresponding aircraft altitude is shown in black.

boundary layer over the Norwegian Sea during this portion of the flight do not impact the results for the pollution events we focus on, which were encountered higher up in the Scandinavian free troposphere and were emitted over continental Europe. The model performance in the Arctic troposphere indicates that the model captures the changing meteorological conditions in the European Arctic at the end of the POLARCAT-France spring campaign (discussed earlier in Sect. 3). This provides confidence that plume transport and dispersion are adequately represented to study aerosol transport and processing.

We evaluate model performance over the European source regions by comparing background aerosol levels from the EMEP network with model results (CTL simulation) extracted at the station locations. Figure 6 shows the comparison for $\mathrm{PM}_{2.5}, \mathrm{SO}_{4}^{=}, \mathrm{NO}_{3}^{-}$, and $\mathrm{NH}_{4}^{+}$, daily averaged for all stations. Error bars show the standard deviation between stations for both measured and modeled aerosols. Overprediction of aerosols on 1 April for $\mathrm{PM}_{2.5}, \mathrm{NO}_{3}^{-}$, and $\mathrm{NH}_{4}^{+}$ correspond to positive biases for these species in the initial conditions (MOZART-4), but WRF-Chem results are in better agreement with measurements after 1 day of simulation. This first day is considered as model spin-up, and is excluded from further analysis. We evaluate the model performance in reproducing European background aerosol lev- els in terms of normalized mean bias (NMB). It is defined as $\mathrm{NMB}=100 \% \times 1 / N \times \sum_{i=1}^{N}\left(M_{i}-O_{i}\right) / O_{i}$, where $M_{i}$ and $O_{i}$ are modeled and observed daily values, averaged over all sites, and the summation is over the $N=10$ days between 2 and 11 April. $\mathrm{PM}_{2.5}$ levels are well reproduced by the model $(\mathrm{NMB}=-0.9 \%)$. There are more significant differences in measured and modeled aerosol composition: while $\mathrm{SO}_{4}^{=}$agrees well with measurements $(\mathrm{NMB}=-0.6 \%), \mathrm{NO}_{3}^{-}$ $(\mathrm{NMB}=+107 \%)$ and $\mathrm{NH}_{4}^{+}(\mathrm{NMB}=+53 \%)$ are overestimated. This suggests that the overestimation of $\mathrm{NO}_{3}^{-}$and $\mathrm{NH}_{4}^{+}$might be compensated in terms of overall mass by an underestimation of organic carbon (OC) aerosols, resulting in relatively good $\mathrm{PM}_{2.5}$ agreement. Due to a lack of available OC measurement from EMEP stations for this period, this hypothesis cannot be verified. If we use the very limited EMEP OC data (5 stations, $67 \%$ coverage), we find that OC is indeed underestimated for those stations ( $\mathrm{NMB}=-38 \%$ ). This underestimation could be caused, in part, by the fact that SOA is not included in our model run. Since SOAs can be formed by the oxidation of VOCs by gas-phase $\mathrm{NO}_{3}$, it is also possible that the lack of SOA is related to the overestimation of nitrate aerosols in our simulations. However, we also note that previous studies including SOA can report errors on OC of the same magnitude or larger (e.g., $-74 \%$ in Tuccella et al., 2012, who attribute this deficiency in modeling OC to an incomplete description of SOA formation in their mechanism).

The overestimation of $\mathrm{NO}_{3}^{-}$and $\mathrm{NH}_{4}^{+}$and underestimation of OC by WRF-Chem in Europe were also seen in the simulations of Tuccella et al. (2012), using different emissions as well as gas and aerosol schemes. That study suggested the discrepancy was due to missing aqueous reactions causing an underestimation of sulfate formation, leading to less neutralization of ammonium by sulfate and favoring the formation of ammonium nitrate (see Meng et al., 1997). The possible role of uncertainties in the simplified wet scavenging scheme used for that study is also highlighted. Our study includes a more complete wet scavenging scheme and the full range of aqueous reactions included in MOSAIC, keeping in mind that cloud-aerosol interaction processes in $\mathrm{MO}$ SAIC are only accounted for in dynamically resolved clouds, which should be underestimated in our simulation $(30 \mathrm{~km}$ horizontal resolution). The inclusion of these processes, and the use of different anthropogenic emissions (EMEP in Tuccella et al., 2012, vs. HTAPv2 in the present study), can explain the better agreement on sulfate compared to Tuccella et al. (2012). However, this better agreement also means that, in our case, sulfate concentrations do not drive the overestimation of modeled ammonium and nitrate. Using EMEP measurements of ammonia (19 stations) and $\mathrm{NO}_{\mathrm{x}}$ (10 stations), we found that $\mathrm{NH}_{3}$ is overestimated by a factor of 2 in our simulation $(\mathrm{NMB}=+108 \%)$, while $\mathrm{NO}_{\mathrm{x}}$ is slightly underestimated $(\mathrm{NMB}=-23 \%)$. This overestimation of $\mathrm{NH}_{3}$ 

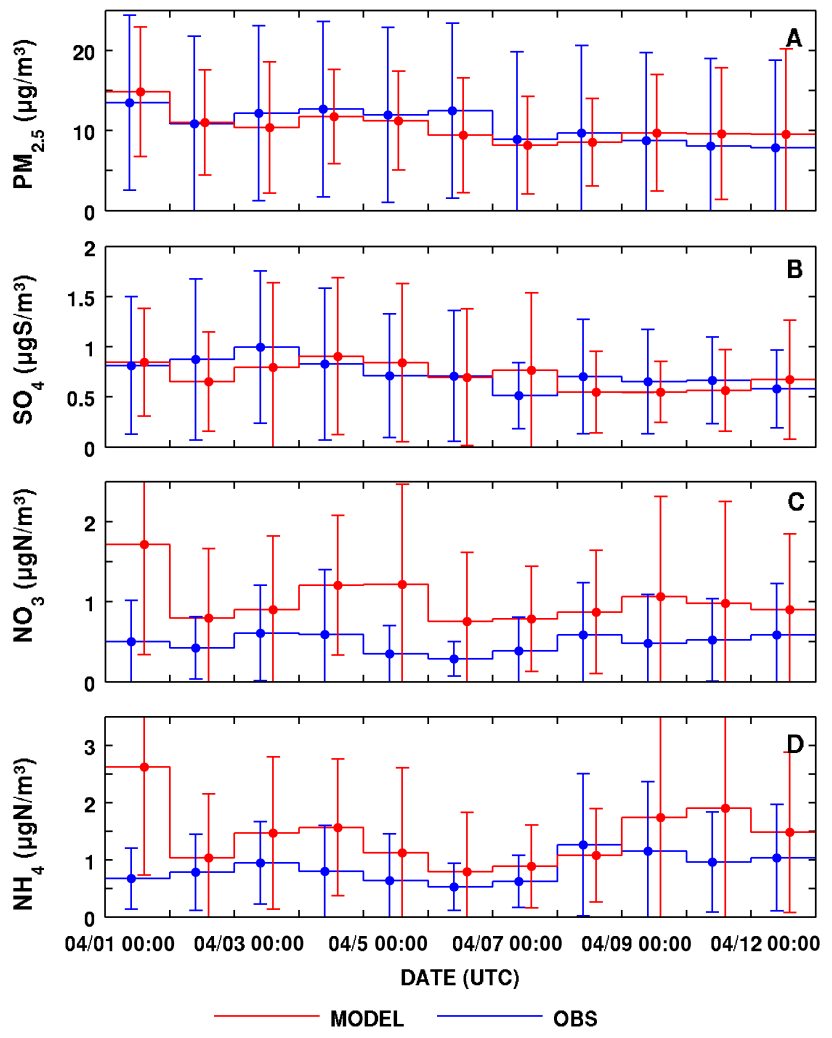

Figure 6. Daily mean aerosol mass measured at EMEP stations within the domain (in blue) and WRF-Chem aerosol mass extracted at the position of the stations (in red) for (a) $\mathrm{PM}_{2.5}$, (b) sulfate aerosol, (c) nitrate aerosol, and (d) ammonium aerosol. The standard deviation between stations is indicated by the error bars.

could cause an enhanced formation of ammonium nitrate, which would explain the model overestimation of ammonium and nitrate.

While the CTL simulation is able to reproduce $\mathrm{PM}_{2.5}$ levels observed in source regions, this good performance is due in part to compensating effects between different chemical components of the aerosols. The bulk hygroscopicity of OC $(\kappa=0.14)$ is lower than the one for $\mathrm{NO}_{3}^{-}$and $\mathrm{NH}_{4}^{+}(\kappa=0.5)$ in MOSAIC. This means that the underestimation of OC in our simulation might lead to overestimated aerosol activation in clouds and wet scavenging. However, refractive indices for $\mathrm{OC}, \mathrm{NH}_{4} \mathrm{NO}_{3}$, and $\left(\mathrm{NH}_{4}\right)_{2} \mathrm{SO}_{4}$ are close (1.45, 1.50 , and 1.47 in MOSAIC), meaning that compensation between these different components should not have a strong impact on modeled aerosol optical properties, and that our model represents European aerosols sufficiently well to investigate the direct and semi-direct aerosol radiative effects in the Arctic.

\section{The origin and properties of springtime aerosols during POLARCAT-France}

In this section, modeled aerosols in the Arctic are compared with POLARCAT-France spring measurements, to investigate in detail the aerosol transport event from Europe to the Arctic. We combine WRF-Chem simulations with FLEXPART-WRF to identify the source regions and transport pathways of plumes sampled during the campaign, and show how they impact processes along transport and the vertical structure of Arctic pollution. First, aerosol particles detected in plumes in April 2008 are described in terms of mass concentrations, chemical composition, and number size distributions. The role of transport pathways and wet scavenging along transport on those properties is also investigated. Aerosol optical properties are then used to quantify the vertical distribution of aerosols as a function of their emission sources.

\subsection{Modeling aerosols measured in situ on 9, 10, and 11 April 2008}

POLARCAT-France measured (in situ) $\mathrm{PM}_{2.5}$ is compared with modeled $\mathrm{PM}_{2.5}$ interpolated in space (model results using hourly output) along the flight tracks on 9, 10, and 11 April 2008 (Fig. 7). The time series of measured $\mathrm{PM}_{2.5}$ shows plumes containing enhanced aerosols were encountered during the flights. Aerosol mass in plumes ranged from 3 to $16 \mu \mathrm{g} \mathrm{m}^{-3}$, while baseline levels were $\sim 1 \mu \mathrm{g} \mathrm{m}^{-3}$. It should be noted that unpolluted air and marine boundary layer air were less frequently sampled due to the planned flight patterns, which targeted anthropogenic and biomass burning influenced plumes. Gray shading denotes periods when in situ measurements are not available, usually due to the presence of clouds.

Air mass origins indicated on Fig. 7 are determined using a combination of WRF-Chem and FLEXPART-WRF (simulations described below). The influence of anthropogenic and biomass burning emissions on the flight track is estimated using the NOANTHRO and NOFIRES sensitivity runs. Specifically, this influence is deemed significant if aerosol mass increased by more than $20 \%$ upon including either anthropogenic or biomass burning emissions, according to the ratios [CTL $\mathrm{PM}_{2.5}$ ] / [NOANTHRO $\mathrm{PM}_{2.5}$ ] and [CTL $\mathrm{PM}_{2.5}$ ] / [NOFIRES PM 2.5 ]. The values of these ratios along the three flight tracks are presented in the Supplement, Fig. S2. We used a threshold of $20 \%$ to highlight the difference between air masses significantly influenced by biomass burning (BB) and air masses mostly influenced by anthropogenic emissions. This threshold excludes air masses weakly influenced (5 to $15 \%$ ) by BB on 10 and 11 April (as seen on Fig. S2) and identifies air masses significant influenced by BB, up to $30-40 \%$. We used the same threshold of $20 \%$ for anthropogenic plumes for consistency. On Fig. 7, pink shading indicates that the modeled $\mathrm{PM}_{2.5}$ are influenced 

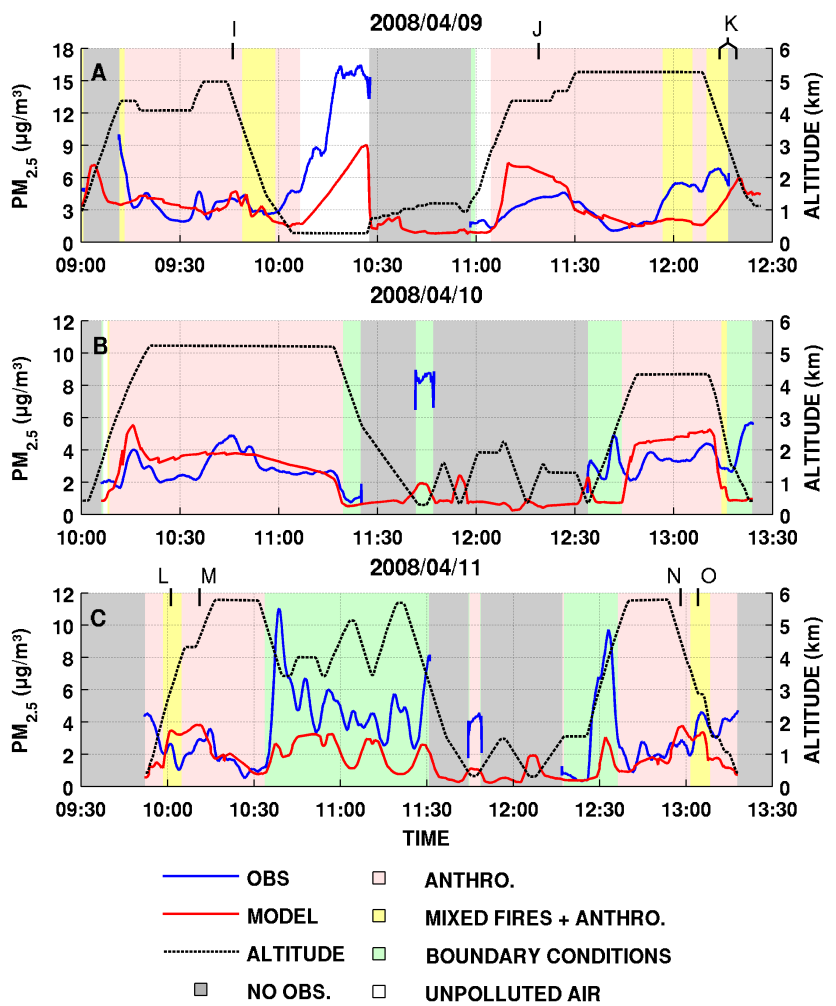

Figure 7. Time series of $\mathrm{PM}_{2.5}$ measured during POLARCATFrance (blue) and modeled (red) with the aircraft altitude indicated in black for the three POLARCAT-France flights on (a) 9 April 2008, (b) 10 April 2008, and (c) 11 April 2008. Grey shading indicates times when no measurements are available. Colors indicate when $\mathrm{PM}_{2.5}$ was significantly influenced ( $>20 \%$ of $\mathrm{PM}_{2.5}$ ) by source: green shows air entering the domain from the northern boundary conditions, pink shows anthropogenic emissions within the domain, yellow shows fire emissions within the domain, and white shows unpolluted air (free of recent pollution sources). Letter labels indicate anthropogenic (I, J, M, N) and mixed anthropogenic/fire $(\mathrm{K}, \mathrm{L}, \mathrm{O})$ plumes investigated further.

by European anthropogenic emissions. Yellow shading indicates portions of the flight influenced by both biomass burning and anthropogenic emissions (mixed plumes). It should be noted that portions of the flight track that are influenced by biomass burning emissions are also influenced by anthropogenic emissions. Green shading indicates that the modeled air mass is significantly influenced by the domain's northern boundary conditions (i.e., air transported from Asia). This influence is identified using FLEXPART-WRF, run in backwards mode with particles released every minute along the flight tracks $(10 \mathrm{~km} \times 10 \mathrm{~km}$ horizontally by $400 \mathrm{~m}$ vertically). When the FLEXPART-WRF retroplume mean trajectory passes closer than five grid cells $(150 \mathrm{~km})$ from the northern end of the domain, the air mass is considered as influenced by the northern boundary conditions. The typical transport pathway of such a plume is shown in the Supplement, Fig. S3. Finally, white shading indicates air masses that are not attributed to a specific source using the methods described above and are referred to as unpolluted air.

In the free troposphere, the model is able to reproduce the baseline $\mathrm{PM}_{2.5}$ levels and the main peaks observed in European air masses for all three flights. The NMB for $\mathrm{PM}_{2.5}$ for all three flights, excluding unpolluted air and boundary condition air, is $+8.8 \%$. Peaks attributed to European anthropogenic emissions are reproduced, although the model cannot capture some small-scale features due to its resolution. At the end of the 9 April flight, two concentrated plumes were sampled in situ around 12:00 and 12:15 UTC. The model identifies these plumes as mixed (anthropogenic/biomass burning), meaning that significant ( $>40 \%$ ) enhancements in modeled $\mathrm{PM}_{2.5}$ at these times are due to biomass burning or anthropogenic European emissions. The first $\mathrm{PM}_{2.5}$ peak is underestimated by the model (around 12:00 UTC), and the second plume (around 12:15 UTC) is located $1.5 \mathrm{~km}$ too low in altitude. This may be due to uncertainties in the injection height for fires or in the intensity and timing of the emissions. However, the issue does not appear to be systematic in our simulation because mixed plume peaks and enhancements are correctly represented during the 11 April flight. Modeled anthropogenic $\mathrm{PM}_{2.5}$ are underestimated below $1 \mathrm{~km}$ at the beginning and end of the 11 April flight above Sweden (discussed in detail in Sect. 5.3). Plumes coming from the northern domain boundary, which are not studied in detail here, reflect a general underestimation of aerosols in the MOZART4 simulation used as the boundary conditions. On 9 April, WRF-Chem also reproduces a large $\mathrm{PM}_{2.5}$ peak located in the marine boundary layer. This peak is composed of more than $95 \%$ sea salt in the model, and corresponds to sea spray uplifted by the strong $20 \mathrm{~m} \mathrm{~s}^{-1}$ winds present in the marine boundary layer in the region of the flight.

The modeled composition of $\mathrm{PM}_{2.5}$ aerosols in anthropogenic and mixed polluted air masses is presented in Table 2. On 9 and 10 April, anthropogenic plumes are mostly composed of nitrate, sulfate, and ammonium aerosol. Mixed plumes contain relatively less nitrate, but more sulfate, organic carbon, and black carbon. The proportion of sulfate is higher in mixed plumes than in anthropogenic plumes, despite the fact that sulfate and $\mathrm{SO}_{2}$ emissions from biomass burning emissions are low. We show in the next section focused on plume origins that the proportion of sulfate is high for mixed plumes because they originate in a region of high anthropogenic $\mathrm{SO}_{2}$ emissions. On 11 April, the composition of anthropogenic plumes and mixed plumes are similar, except for organic carbon, which is still lower in anthropogenic plumes. In Sect. 4, we showed that the model was overestimating nitrate and ammonium at the surface, while probably underestimating organic matter in the European source regions. Measurements of aerosol chemical composition are not available along the POLARCAT-France flights, but were determined during other POLARCAT campaigns in other parts of the Arctic. In situ measurements during other campaigns generally indicate less nitrate and 
Table 2. Modeled $\mathrm{PM}_{2.5}$ aerosol composition by source type along POLARCAT-France spring flights. BC, OC, and SS are black carbon, organic carbon, and sea salt, respectively.

\begin{tabular}{llcccccc}
\hline Flight & Source type & $\begin{array}{r}\mathrm{BC} \\
(\%)\end{array}$ & $\begin{array}{r}\mathrm{OC} \\
(\%)\end{array}$ & $\begin{array}{r}\mathrm{SO}_{4}^{=} \\
(\%)\end{array}$ & $\begin{array}{r}\mathrm{NH}_{4}^{+} \\
(\%)\end{array}$ & $\begin{array}{r}\mathrm{NO}_{3}^{-} \\
(\%)\end{array}$ & $\begin{array}{c}\mathrm{SS} \\
(\%)\end{array}$ \\
\hline \multirow{2}{*}{ 9 Apr 2008 } & Anthro. & 2.5 & 7.0 & 24.1 & 20.6 & 40.2 & 5.6 \\
& Mixed fires + anthro. & 3.2 & 12.6 & 35.0 & 20.1 & 26.0 & 3.2 \\
10 Apr 2008 & Anthro. & 2.3 & 5.5 & 21.7 & 20.9 & 42.4 & 7.3 \\
11 Apr 2008 & Anthro. & 2.7 & 8.7 & 34.4 & 19.5 & 27.3 & 7.4 \\
& Mixed fires + anthro. & 2.8 & 11.9 & 33.9 & 19.4 & 28.5 & 3.4 \\
\hline
\end{tabular}

more organic matter $(\mathrm{OM})$ in Arctic aerosols. For example, Brock et al. (2011) found $78 \% \mathrm{OM}$ and $20 \% \mathrm{NO}_{3}^{-}$ in biomass burning aerosols in the Alaskan Arctic during ARCPAC (32 and 1\% for anthropogenic plumes). Airborne aerosol mass spectrometer measurements in the summer in Greenland during POLARCAT-France (Schmale et al., 2011) also indicate very low $\mathrm{NO}_{3}^{-}$concentrations (below the detection limit) and high proportions of OM (50 to $90 \%)$ in polluted plumes. During the International Chemistry Experiment in the Arctic Lower Troposphere (ICEALOT) campaign, at the same time and location as the POLARCATFrance measurements, Frossard et al. (2011) found (excluding sea salt and black carbon) $30 \% \mathrm{OM}, 60 \% \mathrm{SO}_{4}^{=}$and $1 \%$ $\mathrm{NO}_{3}^{-}$in aerosols found in the Scandinavian marine boundary layer. This comparison with other POLARCAT data also indicates that in our simulations, nitrate aerosols might have been formed at the expense of organic matter, probably due to the lack of a SOA mechanism. The proportion of black carbon modeled in the present study is $2.5 \%$ in anthropogenic air masses (2.6\% for submicron particles), and $3 \%$ in mixed plumes ( $3.1 \%$ for submicron particles). These values are comparable with results from the study of Brock et al. (2011), which found on average $2.4 \%$ submicron mass of BC in anthropogenic plumes and $3.5 \%$ in fire plumes in the Alaskan Arctic during spring 2008.

We evaluate model predictions of aerosol size distributions, which are known to be important for the optical properties (e.g., Boucher, 1998) presented in Sects. 5.3 and 6. It is also important to note that activation in clouds, which is outside the scope of the present study, is also sensitive to aerosol size distributions (Dusek et al., 2006). Plumes for which we compare modeled and measured size distributions are indicated by ticks in Fig. 7 (referring to the modeled aerosol peak). Four anthropogenic plumes (I, J, M, N) and three mixed plumes $(\mathrm{K}, \mathrm{L}, \mathrm{O})$ are investigated. In the case of plume $\mathrm{K}$, the modeled plume peak is located $1 \mathrm{~km}$ lower in the model than in observations, which results in it being displaced later in time along the flight track. For this plume, we compare the modeled and measured plumes using the peak aerosol mass encountered in the model (12:19 UTC) and measurements (12:14 UTC), respectively. This comparison is shown in Fig. 8. It indicates that the model adequately represents the aerosol size distributions with three exceptions. First, the model overestimates the number of particles larger than $300 \mathrm{~nm}$ in the 9 April anthropogenic plumes (I, J). Second, the model cannot be compared to measurements in the smallest MOSAIC bin (aerosols 39 to $78 \mathrm{~nm}$ ), due to the fact that the model does not explicitly resolve nucleation, but relies on a parameterization for nucleation and growth of particles with diameters less than $39 \mathrm{~nm}$. Third, number concentrations are overestimated in the second smallest MOSAIC bin (aerosols 78 to $156 \mathrm{~nm}$ ) for mixed plumes (K and L-O) but not for anthropogenic plumes. We show in Sect. 5.2 that mixed plumes are $\sim 2$ days older than anthropogenic plumes. This means that this overestimation is probably caused by underestimated growth processes, which have the largest impact on older plumes. However, aerosol optical properties are mostly sensitive to particles in the accumulation mode, which is correctly reproduced for all plumes (Stokes diameter ranges for these modes are $90-500 \mathrm{~nm}$ for the anthropogenic plumes, and 110-700 nm for the fire plumes; Quennehen et al., 2012).

\subsection{Origins and transport pathways of anthropogenic and biomass burning plumes sampled during POLARCAT-France}

Different types of aerosols transported to the Arctic during POLARCAT-France display different physical properties and vertical distributions. We investigate how different plume origins and transport pathways result in different aerosol properties in the Arctic. We focus on the role of wet scavenging during transport, which is the largest source of uncertainty in the representation of Arctic aerosols (Schwarz et al., 2010; Browse et al., 2012). Figure 9 shows typical plume transport pathways of an anthropogenic plume (plume J, Fig. 9a and c) and a mixed plume (plume K, Fig. 9b and d) measured during the campaign. Figure $9 \mathrm{a}$ and $\mathrm{b}$ shows the $0-20 \mathrm{~km}$ column of FLEXPART-WRF PES integrated for 7 days for both plumes. It indicates that anthropogenic plumes were mostly influenced by sources in central Europe 2-3 days prior to the measurements, while the mixed plume is 3 to 5 days old and under the influence of emissions in a large region over eastern Europe and western Russia. This region corresponds to the location of agricultural fires in early April 2008, as well 

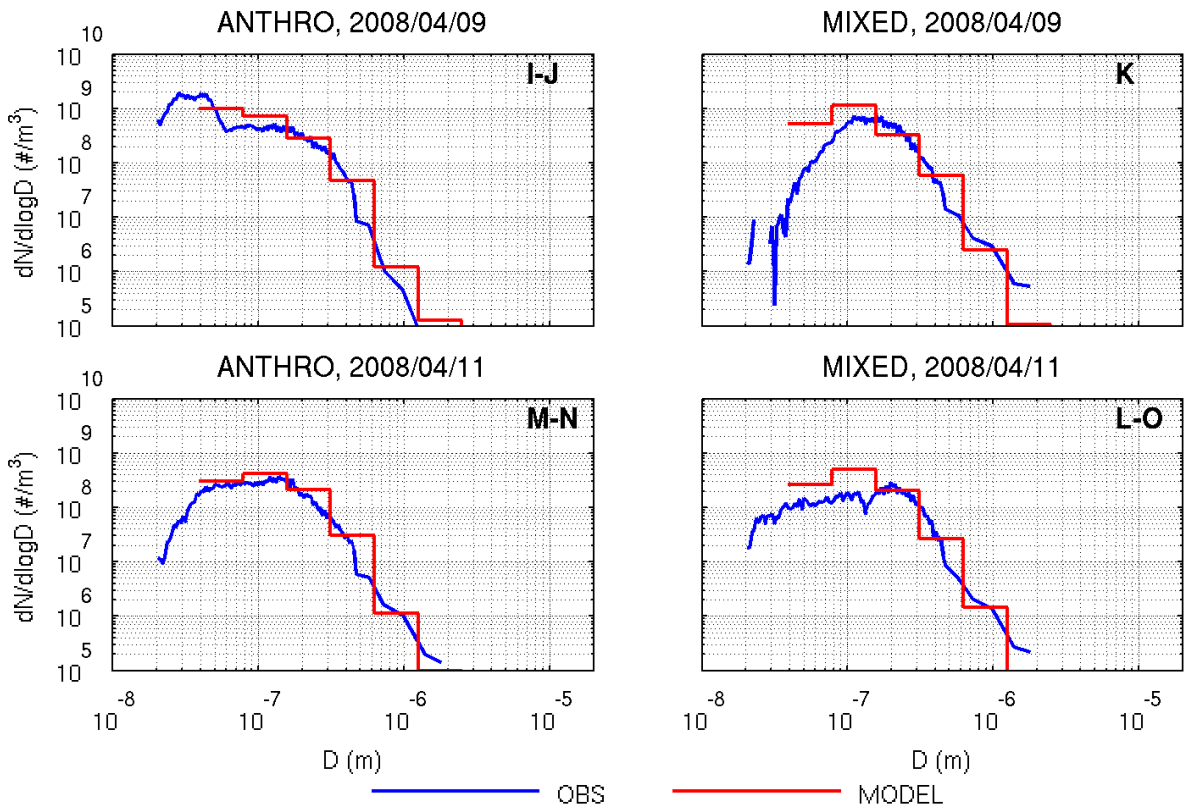

Figure 8. Modeled (red) and measured (blue) number size distributions of plumes labeled (I-O) in Fig. 7, influenced by (I, J, M, N) European anthropogenic and $(\mathrm{K}, \mathrm{L}, \mathrm{O})$ mixed European anthropogenic and fire emissions. Modeled and observed size distributions corresponding to two consecutive samplings of the same plume during the same flight $(\mathrm{I}-\mathrm{J}, \mathrm{M}-\mathrm{N}, \mathrm{L}-\mathrm{O})$ were averaged together.

as significant anthropogenic emissions, especially of $\mathrm{SO}_{2}$, as seen in Fig. 2. The larger age of mixed plumes explain why their size distribution is shifted toward larger sizes than younger anthropogenic plumes, as discussed in Quennehen et al. (2012).

Figure $9 \mathrm{c}$ and $\mathrm{d}$ show the mean altitude for each plume as a function of age. The anthropogenic plume experienced a rapid uplift from 1.5 to $6.5 \mathrm{~km}$ over Poland and the North Sea on 7 or 8 April, associated with the surface low over this region, while the mixed plume was transported to the Arctic below $2 \mathrm{~km}$ and slowly uplifted. Between 9 April and 11 April, FLEXPART-WRF trajectories (not shown here) inform us that mixed plume $\mathrm{K}$ mixed with air from fresher anthropogenic plumes I and J. This mixing explains why the chemical composition of the 11 April mixed plumes, shown in Table 2 and discussed above, is intermediate between 9 April mixed plume $\mathrm{K}$ and the 9 April anthropogenic plumes I and J.

The magnitude of wet scavenging along transport, also represented in Fig. 9c and d, is estimated using the difference between CTL $\mathrm{PM}_{10}$ and NOWETSCAV $\mathrm{PM}_{10}$ along the retroplumes positions. As expected, strong $\mathrm{PM}_{10}$ depletions, reaching $-10 \mu \mathrm{g} \mathrm{m}^{-3}(-74 \%)$ are associated with precipitation during uplift of the anthropogenic plume in the frontal system over Poland, between 37 and $46 \mathrm{~h}$ before it was measured. Although the mixed plume does not experience such a rapid uplift, aerosols are also scavenged by rainout over Finland, between 35 and $45 \mathrm{~h}$ before sampling, decreasing $\mathrm{PM}_{10}$ levels by $17 \mu \mathrm{g} \mathrm{m}^{-3}(-55 \%)$. The accumulated precipitation in the simulation compared to the E-OBS
European daily gridded precipitation data set (Haylock et al., 2008), shows that while WRF-Chem correctly reproduces the precipitation patterns observed during this period, it generally underestimates their intensity (see Supplement, Fig. S4). However, we have shown that average $\mathrm{PM}_{2.5}$ levels are well reproduced in the source regions and in the Arctic, indicating that losses along transport are relatively well reproduced. This could be explained by compensations between underestimated precipitations and an overestimated wet scavenging rate in our simulation. An overestimation of the wet scavenging rate could be caused by the overestimated hygroscopy of the modeled aerosol, which contains too much ammonium and nitrate, and not enough organic matter.

\subsection{Vertical aerosol distributions: 9 April 2008}

The vertical structure of aerosol layers transported to the Arctic is often complex (Brock et al., 2011), and the vertical distribution of absorbing aerosol layers can have a large influence on their radiative effects (e.g., Meloni et al., 2005; Raut and Chazette, 2008). Here, the modeled vertical structure of aerosol layers in the Arctic troposphere is evaluated using the pseudo-backscatter ratio at $532 \mathrm{~nm}$ (PBR) measured by the airborne lidar shooting at nadir. The measured PBR is represented in Fig. 10b for the 9 April flight, clouds and data below clouds are masked in white. The altitude of the aircraft, which flew north to south and returned to Kiruna, is shown as a black line on panels b to e. We choose to show the 9 April flight because modeled low-level pollution is not influenced by the model northern boundary conditions 

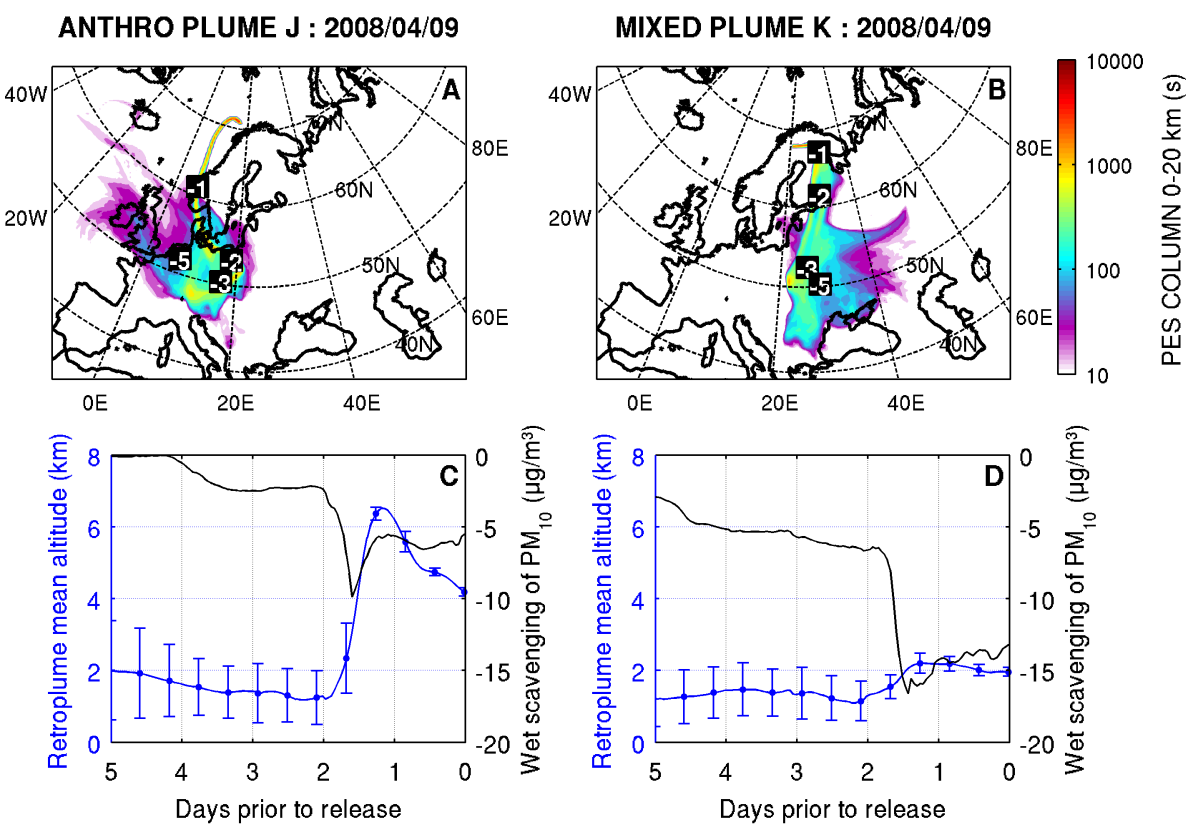

Figure 9. Backward mode FLEXPART-WRF column-integrated PES (a and b), showing typical transport pathways for an anthropogenic plume (left, plume J, originating on 9 April 2008 at 11:19 UTC on the POLARCAT flight track) and a mixed anthropogenic/biomass burning plume (right, plume K, originating on 9 April 2008 at 12:19 UTC on the flight track). Numbers in white indicate the plume age, in days. Panels (c) and (d) show each plume's mean altitude with rms error bars showing vertical dispersion (blue) and the difference between the CTL $\mathrm{PM}_{10}$ and the NOWETSCAV PM 10 along transport, indicating wet scavenging events (black).

on this day. The model-to-observation comparison is therefore not affected by the performance of the global model MOZART-4. Figure 10a shows the $\mathrm{PM}_{2.5}$ measured in situ by the aircraft during the same period. The $\mathrm{PM}_{2.5}$ and lidarderived PBR just below the aircraft present a very similar evolution: the $\mathrm{PM}_{2.5}$ and PBR signals are enhanced during the whole leg between 4 and $5 \mathrm{~km}$, at the aircraft altitude, and just below. This good correlation $\left(r^{2}=0.86\right.$, see Fig. S5) between aerosol mass and optical properties allows us to validate aerosol concentrations' vertical distributions through their optical properties.

The PBR at $532 \mathrm{~nm}$ is compared to cross sections of the simulated backscatter ratio (Fig. 10c), simulated $\mathrm{PM}_{2.5}$ (Fig. 10d) and simulated aerosol number concentration (Fig. 10e) extracted along flight tracks from the WRF-Chem simulation. The magnitude of the PBR is correctly reproduced, with background regions between 1 and 1.1, and visible aerosol layers reaching values of 1.3 to 1.5 . Peak intensities in plumes transported to the Arctic region tend to be underestimated by the model, as the modeled plumes are too diluted vertically. Plume locations are reasonably well reproduced with an enhanced layer at $5 \mathrm{~km}$ during the whole flight leg, and two main layers at lower latitudes and altitudes, between 1.5-2 and 3-4 km. One enhanced layer measured between 11:30 and 11:50 UTC at $1 \mathrm{~km}$ is missing from the modeled PBR cross section because it is displaced $\sim 50 \mathrm{~km}$ to the southwest in the simulation (see Supplement, Fig. S6).
This displacement is probably due to the cumulative effect of small errors on wind speed and wind direction over the 3 to 5 days of long-range transport. The model underestimates the PBR in the intense layer measured in situ and by the lidar at $5 \mathrm{~km}$ at 12:00 UTC, which is in agreement with the underestimation observed on $\mathrm{PM}_{2.5}$ levels previously described in Fig. 7. This layer, identified as a 5-day old mixed plume in the model, features low $\mathrm{PM}_{2.5}$ but high aerosol number concentrations (Fig. 10e), suggesting it is mostly composed of small particles. This means that the discrepancy in this layer probably corresponds to underestimated growth by condensation, which could be associated with underestimated precursor emissions including a lack of SOA. This is in agreement with the comparison of the modeled and observed size distributions of aerosols in mixed plumes, discussed in Sect. 5.1, which indicated underestimated particle growth in the older mixed plumes.

We investigate the vertical distribution of modeled anthropogenic and biomass burning aerosols during this profile, and the impact of wet scavenging on the vertical distribution. Figure 11 shows the sensitivity of the $\mathrm{PM}_{2.5}$ vertical cross section to anthropogenic emissions (Fig. 11a), biomass burning emissions (Fig. 11b), and wet scavenging (Fig. 11c). During the 9 April flight, anthropogenic emissions have the largest influence in the mid- to upper troposphere, above $4 \mathrm{~km}$ and in the PBL and lower troposphere, below $2 \mathrm{~km}$, while the impacts of biomass burning emissions are more pronounced be- 


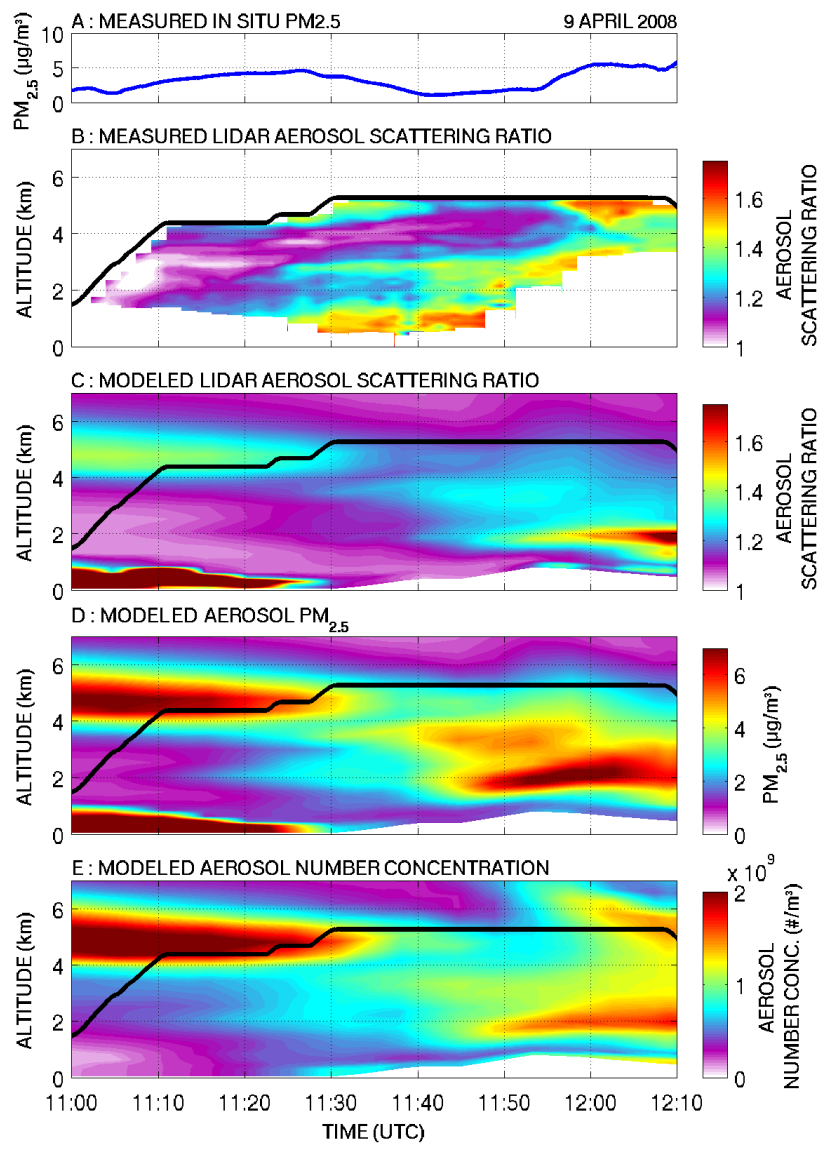

Figure 10. (a) $\mathrm{PM}_{2.5}$ measured in situ during the last part of the 9 April 2008 flight, (b) lidar $532 \mathrm{~nm}$ pseudo-backscatter ratio measured at nadir during the same portion of the flight (altitude in black, white areas represent topography or cloudy areas where no aerosol data is available), (c) simulated WRF-Chem lidar $532 \mathrm{~nm}$ pseudobackscatter ratio, (d) modeled $\mathrm{PM}_{2.5}$ cross section at the same position, and (e) modeled aerosol number concentration cross section at the same position.

tween 2 and $4 \mathrm{~km}$. Figure $11 \mathrm{~b}$ confirms that the plume missing at $5 \mathrm{~km}$ in Fig. 10c is indeed due to biomass burning emissions, but the associated enhancement above background is very low, around $1 \mu \mathrm{g} \mathrm{m}^{-3}$. According to Fig. 11c, this low enhancement is not due to high wet scavenging in this layer. As discussed before, this confirms that the underestimation of $\mathrm{PM}_{2.5}$ in this layer may be due to insufficient growth by condensation in this plume. The impact of wet scavenging is the strongest for the lower-level mixed pollution, as discussed in the case of plume $\mathrm{K}$ in Fig. 9d. It is negligible in biomass burning layers located between 2 and $4 \mathrm{~km}$, and strong relatively to total $\mathrm{PM}_{2.5}$ in the southernmost and lowaltitude anthropogenic layer.
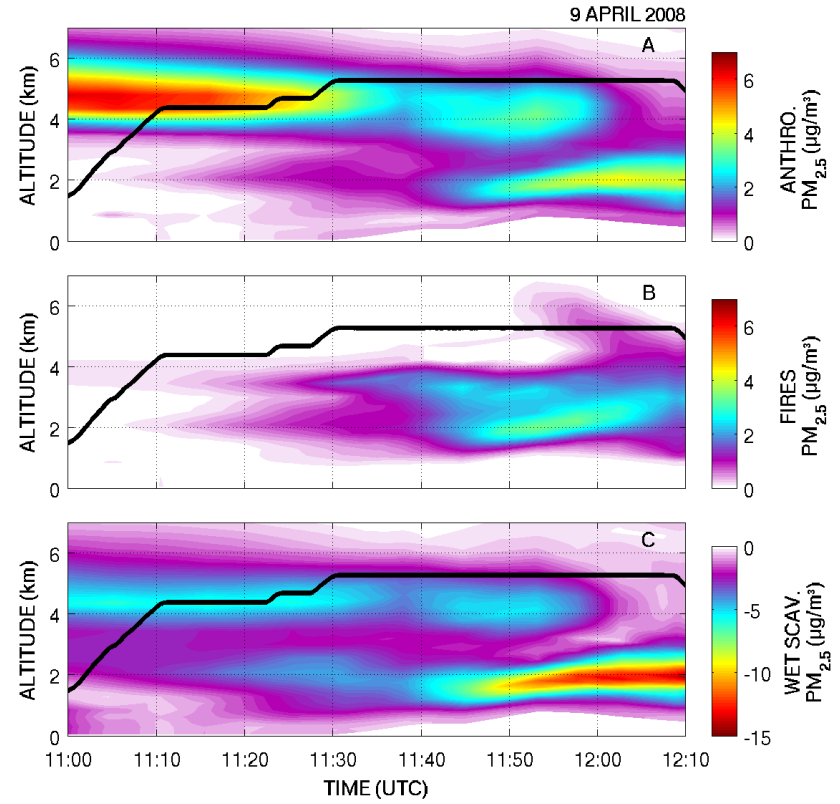

Figure 11. Modeled aerosol cross sections along the flight track (plane altitude in black), showing the sensitivity of the modeled $\mathrm{PM}_{2.5}$ to (a) anthropogenic emissions, (b) fire emissions, and (c) wet scavenging.

\section{Impacts of European aerosol transport on the Arctic}

Results presented so far give us confidence in the way this transport event is represented in our simulation in terms of meteorology, $\mathrm{PM}_{2.5}$ levels, size distributions, spatial extent, and vertical structure of the plumes. We now investigate the regional impacts of this transport event in the European Arctic region. Figure 12 shows the average vertical profiles of the modeled anthropogenic and biomass burning contributions to $\mathrm{PM}_{2.5}$ (total and chemically speciated) north of the Arctic Circle (within the model domain) during the period from 00:00 UTC 8 April to 00:00 UTC 12 April. The very low aerosol concentrations are due to area-weighted averaging of European enhancements confined in the lower Scandinavian Arctic with the rest of the clean Arctic region contained in the domain. Because of this, we will not discuss the absolute enhancements and instead focus on relative values. This average profile shows the same general features as were observed in situ and by lidar during POLARCATFrance, with anthropogenic emissions separated between a low-altitude $(1.5 \mathrm{~km})$ and a high-altitude $(4.5 \mathrm{~km})$ contribution, and biomass burning emissions impacting intermediate altitudes $(2.5-3 \mathrm{~km})$. Different species display different vertical structures: for the anthropogenic contribution, $\mathrm{BC}, \mathrm{OC}$, and $\mathrm{SO}_{4}^{=}$are enhanced at low altitudes. This corresponds to the mixed layers from eastern Europe and Russia. High-altitude anthropogenic plumes from central $\mathrm{Eu}-$ rope contain enhanced $\mathrm{NH}_{4}^{+}, \mathrm{NO}_{3}^{-}$, and $\mathrm{BC}$. Biomass burning plumes contain larger mass fractions of $\mathrm{BC}$ and $\mathrm{OC}$ 

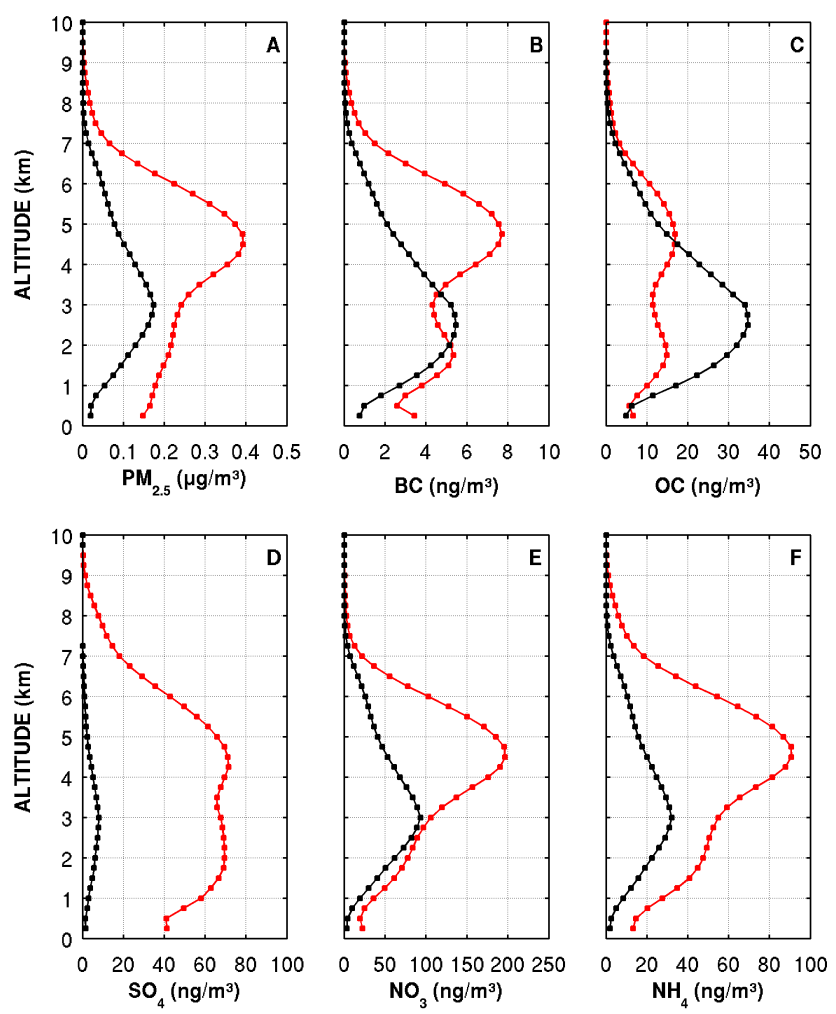

ANTHRO $\longrightarrow$ FIRES

Figure 12. Modeled vertical profiles of enhancements in (a) $\mathrm{PM}_{2.5}$, (b) $\mathrm{BC}$, (c) $\mathrm{OC}$, (d) $\mathrm{SO}_{4}^{=}$, (e) $\mathrm{NO}_{3}^{-}$, and (f) $\mathrm{NH}_{4}^{+} \mathrm{PM}_{2.5}$, due to anthropogenic (red) and fire (black) emissions within the WRFChem model domain, averaged in the Arctic (latitude $>66.6^{\circ} \mathrm{N}$ ) and over the period from 00:00 UTC 8 April 2008 to 00:00 UTC 12 April 2008.

than anthropogenic plumes, and BC and OC influence lower altitudes than other $\mathrm{PM}_{2.5}$ species from biomass burning. These results are in agreement with earlier studies by Stohl et al. (2007) and Lund Myhre et al. (2007), who analyzed cases of transport of biomass burning plumes from eastern Europe to the Arctic in spring 2006. Using FLEXPART simulations and lidar measurements, they showed that biomass burning aerosols were mostly confined below $3 \mathrm{~km}$ altitudes in the Arctic. Fisher et al. (2011) investigated aerosol transport from the mid-latitudes to the Arctic during April 2008 with the global chemical transport model GEOS-Chem, and found that in the high Arctic $\left(75-85^{\circ} \mathrm{N}\right), \mathrm{NH}_{4}^{+}$and $\mathrm{SO}_{4}^{=}$were sensitive to European anthropogenic emissions at all altitudes, with a peak sensitivity between 2 and $5 \mathrm{~km}$.

Pueschel and Kinne (1995) have shown that layers of aerosols containing black carbon, even with very high single scattering albedos (0.98), could warm the atmosphere over snow- or ice-covered surfaces. Because the transport of pollution from Europe to the Arctic is especially efficient in late winter and early spring when the Scandinavian snow cover is still extensive, aerosols transported to the Scandinavian
Arctic may contribute to enhanced local atmospheric heating rates in this region (Flanner, 2013). We investigate this by calculating the DSRE $(0.125$ to $10 \mu \mathrm{m}$ wavelengths $)$ of aerosols at the top of atmosphere (TOA), in regions significantly influenced by in-domain anthropogenic and biomass burning emissions. The DSRE, shown in Fig. 13a, is estimated by taking the difference between the upward shortwave TOA flux calculated online by the Goddard shortwave module within WRF-Chem, in the CTL simulation minus the NODIRECT simulation. Because WRF-Chem upward radiative fluxes are by convention always negative, positive DSRE values at TOA indicate heating of the surfaceatmosphere column. The DSRE is averaged over the period from 00:00 UTC 8 April to 00:00 UTC 12 April. In-domain anthropogenic and biomass burning emissions are considered significant if the $\mathrm{PM}_{2.5}$ column sensitivity to anthropogenic and biomass burning emissions (shown in Fig. 13b) exceeds $50 \%$ of the total column of CTL $\mathrm{PM}_{2.5}$. We added this condition to exclude from our calculation of the DSRE the areas where the dominant contribution is due to aerosols originating from the boundary conditions (i.e., the Asian plume), from natural emissions (i.e., sea salt) or from background levels.

As expected, the DSRE is negative over land and ocean where snow and ice cover are low, but positive over regions with high snow and ice covers (see the snow and ice cover map on Fig. 13c). The 4-day average value of the DSRE at TOA north of $60^{\circ} \mathrm{N}$ in regions significantly influenced by European pollution is shown in Table 3. In addition to the total average effect north of $60^{\circ} \mathrm{N}$, we compute values for the DSRE over surfaces with extensive snow and ice cover $(>90 \%)$, and over the ocean surface. On average, the European aerosols have a cooling effect north of $60^{\circ} \mathrm{N}$ $\left(-0.98 \mathrm{~W} \mathrm{~m}^{-2}\right)$. Over snow and ice, the average DSRE is $+0.58 \mathrm{~W} \mathrm{~m}^{-2}$, peaking near $+2 \mathrm{~W} \mathrm{~m}^{-2}$ over a large region in northern Scandinavia where AODs are the highest $(\sim 0.5$ at $400 \mathrm{~nm}$ ). The DSRE is much lower over the Russian snowpack east of $42^{\circ} \mathrm{E}$ because the European mixed air mass in this region is either optically shallow (AOD from 0.05 to 0.2 ) or is located below clouds. Over the Arctic seas, the DSRE is negative due to the lower albedo of the ocean surface. The calculated DSRE in oceanic regions north of $60^{\circ} \mathrm{N}$ influenced by the European plumes is $-1.5 \mathrm{~W} \mathrm{~m}^{-2}$. Minimum values reach close to $-5 \mathrm{~W} \mathrm{~m}^{-2}$ over the Norwegian Sea close to the coast of Norway, where the cloud cover is the lowest, as shown in Fig. 13d.

In this study, we focus on the springtime European Arctic and put our results into the context of other studies focusing on the same period in different locations within the Arctic. We summarize the other studies for comparison, but leave it to future studies to draw broader conclusions about whether these results are representative of wider spatial and temporal scales. Brock et al. (2011) calculated a direct radiative effect of $+3.3 \mathrm{~W} \mathrm{~m}^{-2}$ over snow at TOA for the average of 10 typical polluted profiles measured dur- 

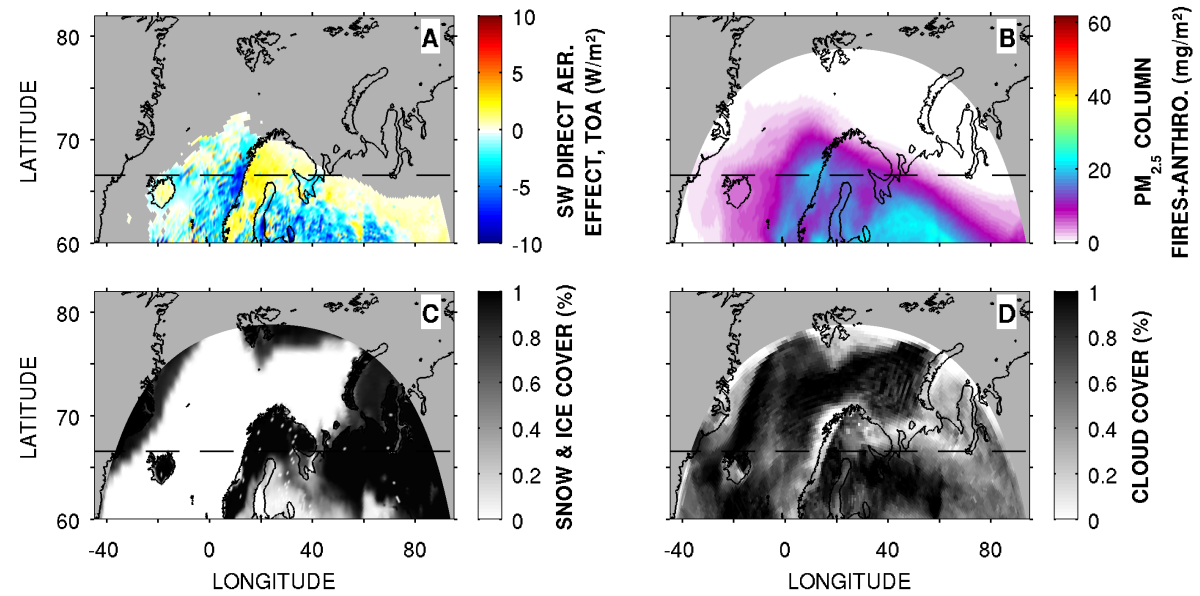

Figure 13. Model averages over the period from 00:00 UTC 8 April 2008 to 00:00 UTC 12 April 2008 of the (a) aerosol DSRE, at the TOA, in regions significantly affected by in-domain anthropogenic and fire emissions, (b) $\mathrm{PM}_{2.5}$ column sensitivity to anthropogenic and biomass burning emissions, and (c) fractional snow and sea ice cover, (d) fractional cloud cover. In panel (a), regions not significantly affected by in-domain emissions are masked in gray. In panels (b-d), regions outside of the WRF-Chem domain are masked in gray. The Arctic Circle is indicated by a dashed line.

Table 3. Four-day average DSRE at the TOA north of $60^{\circ} \mathrm{N}$, over regions significantly influenced by European pollution $(>50 \%$ of total $\mathrm{PM}_{2.5}$ column due to in-domain anthropogenic and biomass burning emissions).

\begin{tabular}{ll}
\hline Type of land surface & $\begin{array}{l}\text { DSRE at TOA } \\
\left(\mathrm{W} \mathrm{m}^{-2}\right)\end{array}$ \\
\hline Snow and ice cover $>90 \%$ & +0.58 \\
Ocean & -1.52 \\
All & -0.98 \\
\hline
\end{tabular}

ing the ARCPAC campaign, not taking the semi-direct effect into account. Maximum modeled BC in WRF-Chem along the POLARCAT-France flight tracks is $150 \mathrm{ng} \mathrm{m}^{-3}$ (anthropogenic) and $260 \mathrm{ng} \mathrm{m}^{-3}$ (mixed fire/anthropogenic), which are comparable with the average $\mathrm{BC}$ values reported for anthropogenic $\left(148 \mathrm{ng} \mathrm{m}^{-3}\right)$ and fire plumes $\left(312 \mathrm{ng} \mathrm{m}^{-3}\right)$ in Brock et al. (2011). This means that, on average, the $\mathrm{BC}$ values for pollution-influenced plumes in our simulation are lower than values reported by Brock et al. (2011). Quinn et al. (2007) found a similar direct radiative effect value of $+2.5 \mathrm{~W} \mathrm{~m}^{-2}$ over snow at TOA for the average polluted conditions encountered during the Arctic haze maximum at Barrow. Those results were obtained at solar noon, in clear sky conditions, over snow, and in polluted regions only, conditions that lead to a maximum direct effect. Using a similar approach, we compute the DSRE in regions influenced by European pollution, close to noon (11:00 UTC), and above high snow covers $(>90 \%)$. This results in an average DSRE of $+1.9 \mathrm{~W} \mathrm{~m}^{-2}$ north of $60^{\circ} \mathrm{N}$. If we exclude the snowpack in Russia, east of $42^{\circ} \mathrm{E}$, the average DSRE in reaches $+3.3 \mathrm{~W} \mathrm{~m}^{-2}$. These values are in agreement with results from Brock et al. (2011) and Quinn et al. (2007). It should be noted that our retrievals are done in all-sky conditions and not exactly at local solar noon, introducing a slight low bias. Including the semi-direct effect in our calculations might have introduced a warming bias, which would be limited by the nudging of WRF-Chem temperature, relative humidity, and wind speed towards FNL reanalyses in the free troposphere. We verified that differences in cloud cover between the NODIRECT and CTL simulations were limited in magnitude and extent, with only a few local points over the sea affected (below $10 \%$ cloud cover change for the 8 to 12 April average), that mostly cancel each other out when regionally averaged.

Lund Myhre et al. (2007) calculated the direct forcing of biomass burning aerosols transported from Europe to the Arctic in late April and early May 2006 from spaceborne AOD measurements. For those exceptionally intense plumes, they found that the cooling direct effect at TOA reached $-35 \mathrm{~W} \mathrm{~m}^{-2}$ over the regions with the highest AOD in the Barents Sea, while the maximum warming direct effect over snow was limited to $+5 \mathrm{~W} \mathrm{~m}^{-2}$ over Svalbard. Keeping in mind that our results are not directly comparable because of the different times of year and different averaging periods, we found a 4-day average direct and semi-direct effect reaching maximum values of $+2 \mathrm{~W} \mathrm{~m}^{-2}$ over snow-covered Scandinavia, and maximum cooling values of $-5 \mathrm{Wm}^{-2}$ over the Norwegian Sea. Several reasons could explain this different balance between warming and cooling effects. In our case, modeled European plumes contained higher levels of black carbon ( 2.5 to $3 \%$ of submicron aerosol mass) than the measured value used in the study of Lund Myhre et al. $(2007 ; 1.98 \%)$. The transport event studied here also featured a high-altitude anthropogenic plume that would 
have a local warming effect above the high-albedo low-level clouds. The inclusion of the semi-direct effect in our study might have also played a limited role.

At the surface, the direct aerosol effect causes local cooling for all types of land surfaces, including snow and ice $\left(-1.1 \mathrm{~W} \mathrm{~m}^{-2}\right.$ DSRE on average, $-2.75 \mathrm{~W} \mathrm{~m}^{-2}$ at noon over Scandinavia and Finland). However, we also show in Fig. 12 that $\mathrm{BC}$ was enhanced at the surface in anthropogenic plumes, which could lead to surface warming through the effects of BC deposited on snow. Black carbon deposition is not coupled to snow albedo in WRF-Chem 3.5.1, however the global model study of Wang et al. (2011) showed that in spring 2008 (April-May), significant levels of anthropogenic $\mathrm{BC}$ ( 1 to $5 \mathrm{mg} \mathrm{Cm}^{-2}$ month $^{-1}$ ) were deposited on snow in northern Europe, leading to 1 to $2 \%$ change in the regional albedo of snow and ice. This change in snow albedo was estimated to cause a radiative effect of $+1.7 \mathrm{~W} \mathrm{~m}^{-2}$ in April-May (average value for the Arctic north of $60^{\circ} \mathrm{N}$ ). Wang et al. (2011) did not show the geographical distribution of this forcing, which should be higher in Scandinavia and Finland because the snow-albedo change from $\mathrm{BC}$ deposition is higher in their study in continental Eurasia than in the rest of the Arctic.

\section{Summary and conclusions}

In this study, we investigate an aerosol transport event from Europe to the European Arctic using measurements as well as regional chemical transport model simulations for the first time. Specifically, an event involving long-range transport of biomass burning and anthropogenic aerosols from $\mathrm{Eu}-$ rope to the Arctic in April 2008 is studied using the regional model WRF-Chem (eight-bin MOSAIC aerosol scheme), to quantify impacts on aerosol concentrations and resulting direct shortwave radiative effects in the Scandinavian Arctic. Modeled aerosols are evaluated against ground-based observations from the EMEP network in European source regions, and using POLARCAT-France aircraft measurements aloft in the European Arctic. The model reproduces background $\mathrm{PM}_{2.5}$ levels at EMEP ground-based stations in Europe $(\mathrm{NMB}=-0.9 \%)$ and in Arctic polluted air masses measured by the ATR42 aircraft $(\mathrm{NMB}=+8.8 \%)$. Comparison with EMEP measurements shows that the model overestimates concentrations of particulate $\mathrm{NO}_{3}^{-}(\mathrm{NMB}=+107 \%)$ and $\mathrm{NH}_{4}^{+}(\mathrm{NMB}=+53 \%)$ in source regions, probably because of overestimated $\mathrm{NH}_{3}$ emissions and the lack of SOA formation, and may underestimate OC. Good agreement is found between simulated $\mathrm{SO}_{4}^{=}$and EMEP measurements $(\mathrm{NMB}=-0.6 \%)$.

The model indicates that European biomass burning and anthropogenic emissions both had a significant influence on total aerosol mass concentrations ( $>20 \%$ of total $\mathrm{PM}_{2.5}$ ) during portions of the POLARCAT-France spring campaign measurements analyzed in this study. Plumes influenced by biomass burning sources in the model are also found to be significantly influenced by anthropogenic emissions. These modeled mixed plumes contain elevated organic carbon and black carbon concentrations. They originated in eastern Europe and western Russia, and followed low-altitude (below $2 \mathrm{~km}$ ) transport pathways into the Arctic. Significant wet scavenging is predicted in the model during transport over Finland, reducing $\mathrm{PM}_{10}$ levels by $55 \%$. Modeled highaltitude anthropogenic plumes, originating in central Europe, were rapidly uplifted (from 1 to $6 \mathrm{~km}$ in less than $24 \mathrm{~h}$ ) by warm conveyor belt circulations over Poland and the North Sea. The model also predicts significant wet scavenging during transport of these anthropogenic plumes $\left(\mathrm{PM}_{10}\right.$ reduced by $74 \%$ ). Evaluation of the model against in situ measurements and lidar profiles below the aircraft shows that the model correctly represents the average vertical distribution of aerosols during this European transport event, as well as the magnitude of the aerosol optical properties. However, this comparison suggests that the model underrepresents the rate of aerosol growth processes, especially condensation, which has the largest impact on the older mixed plumes ( 3 to 5 days old).

The model is used to investigate the average vertical structure of aerosol enhancements from European anthropogenic and biomass burning emissions in the Scandinavian Arctic. Anthropogenic emissions are shown to influence aerosols at both low $(\sim 1.5 \mathrm{~km})$ and higher altitudes $(\sim 4.5 \mathrm{~km})$, while biomass burning emissions influence aerosols between these altitudes (2.5 to $3 \mathrm{~km}$ ). In anthropogenic plumes, BC and $\mathrm{SO}_{4}^{=}$aerosol concentrations are proportionally more enhanced at lower altitudes, including at the surface.

This transport event brought elevated aerosol concentrations north of the Arctic Circle for a rather short period of 4 days, from 8 to 12 April 2008. Due to the location of the polar front, these European aerosols did not mix significantly with local Arctic air further north. However, this event is particularly interesting because of the extensive seasonal snow cover present in northern Scandinavia during this period. We show that the event had a significant local atmospheric warming effect over snow and ice surfaces. The average $96 \mathrm{~h}$ TOA direct and semi-direct shortwave radiative effect from this event over snow and sea ice is found to be $+0.58 \mathrm{~W} \mathrm{~m}^{-2}$ north of $60^{\circ} \mathrm{N}$. At solar noon, in regions significantly influenced by European aerosols, larger warming is predicted, $+3.3 \mathrm{~W} \mathrm{~m}^{-2}$ (TOA direct and semi-direct radiative effects) over the Scandinavian and Finnish snow cover north of $60^{\circ} \mathrm{N}$. This result is of the same order of magnitude as values previously reported for aerosols in the western Arctic (Brock et al., 2011; Quinn et al., 2007).

These radiative effect values do not include the impacts of cloud-aerosol interactions, which could be significant due to the extensive cloud cover in northern Scandinavia during this transport event. The indirect effect could offset the warming effect of European aerosols over snow and icecovered surfaces we have shown here. Moreover, the indi- 
rect aerosol effect is still uncertain, especially in the Arctic, and further work is needed to estimate its magnitude. During POLARCAT-France, the ATR-42 aircraft also sampled an intense Asian plume that was not investigated in this study, which focuses on European aerosols. The contribution of Asian sources to Arctic pollution is an active area of research, and the POLARCAT-France data set, as well as the other POLARCAT data sets, could be the basis of a focused study on the transport of such plumes to the Arctic.

\section{The Supplement related to this article is available online at doi:10.5194/acp-15-3831-2015-supplement.}

Acknowledgements. This study was supported by the French research agency ANR Climate Impacts of Short-Lived Pollutants and Methane in the Arctic (CLIMSLIP) project and CNRS/LEFE. We also acknowledge support from the ANR "Programme d'Investissements d'Avenir" (grant no. ANR-10-LABX-0018). Financial support for this work was provided by Total. The UMS SAFIRE is acknowledged for supporting the ATR-42 aircraft deployment and for providing the aircraft meteorological data. The POLARCAT-FRANCE project was supported by ANR, CNES, CNRS/INSU, and IPEV. We thank Jerome Brioude (CIRES) for the development of FLEXPART-WRF. We thank the EDGAR team for compiling the HTAPv2 emissions (http://edgar.jrc.ec.europa.eu/htap_v2/index.php?SECURE=123).

We acknowledge the E-OBS data set from the EU-FP6 project ENSEMBLES (http://ensembles-eu.metoffice.com) and the data providers in the ECA\&D project (http://www.ecad.eu). Computing resources were provided by the IPSL CICLAD/CLIMSERV mesocenter.

Edited by: R. Krejci

\section{References}

Ackerman, A. S., Toon, O. B., Stevens, D. E., Heymsfield, A. J., Ramanathan, V., and Welton, E. J.: Reduction of tropical cloudiness by soot, Science, 288, 1042-1047, doi:10.1126/science.288.5468.1042, 2000.

Albrecht, B. A.: Aerosols, Cloud Microphysics, and Fractional Cloudiness, Science, 245, 1227-1230, 1989.

Ancellet, G., Pelon, J., Blanchard, Y., Quennehen, B., Bazureau, A., Law, K. S., and Schwarzenboeck, A.: Transport of aerosol to the Arctic: analysis of CALIOP and French aircraft data during the spring 2008 POLARCAT campaign, Atmos. Chem. Phys., 14, 8235-8254, doi:10.5194/acp-14-8235-2014, 2014.

Barrie, L. A.: Arctic air pollution: an overview of current knowledge, Atmos. Environ., 20, 643-663, 1986.

Bessagnet, B., Menut, L., Curci, G., Hodzic, A., Guillaume, B., Liousse, C., Moukhtar, S., Pun, B., Seigneur, C., and Schulz, M.: Regional modeling of carbonaceous aerosols over Europe-focus on secondary organic aerosols, J. Atmos. Chem., 61, 175-202, doi:10.1007/s10874-009-9129-2, 2008.
Bond, T. C., Habib, G., and Bergstrom, R. W.: Limitations in the enhancement of visible light absorption due to mixing state, J. Geophys. Res., 111, D20211, doi:10.1029/2006JD007315, 2006.

Boucher, O.: On aerosol direct shortwave forcing and the HenyeyGreenstein phase function, J. Atmos. Sci., 55, 128-134, 1998.

Brioude, J., Arnold, D., Stohl, A., Cassiani, M., Morton, D., Seibert, P., Angevine, W., Evan, S., Dingwell, A., Fast, J. D., Easter, R. C., Pisso, I., Burkhart, J., and Wotawa, G.: The Lagrangian particle dispersion model FLEXPART-WRF version 3.1, Geosci. Model Dev., 6, 1889-1904, doi:10.5194/gmd-61889-2013, 2013.

Brock, C. A., Cozic, J., Bahreini, R., Froyd, K. D., Middlebrook, A. M., McComiskey, A., Brioude, J., Cooper, O. R., Stohl, A., Aikin, K. C., de Gouw, J. A., Fahey, D. W., Ferrare, R. A., Gao, R.-S., Gore, W., Holloway, J. S., Hübler, G., Jefferson, A., Lack, D. A., Lance, S., Moore, R. H., Murphy, D. M., Nenes, A., Novelli, P. C., Nowak, J. B., Ogren, J. A., Peischl, J., Pierce, R. B., Pilewskie, P., Quinn, P. K., Ryerson, T. B., Schmidt, K. S., Schwarz, J. P., Sodemann, H., Spackman, J. R., Stark, H., Thomson, D. S., Thornberry, T., Veres, P., Watts, L. A., Warneke, C., and Wollny, A. G.: Characteristics, sources, and transport of aerosols measured in spring 2008 during the aerosol, radiation, and cloud processes affecting Arctic Climate (ARCPAC) Project, Atmos. Chem. Phys., 11, 2423 2453, doi:10.5194/acp-11-2423-2011, 2011.

Browse, J., Carslaw, K. S., Arnold, S. R., Pringle, K., and Boucher, O.: The scavenging processes controlling the seasonal cycle in Arctic sulphate and black carbon aerosol, Atmos. Chem. Phys., 12, 6775-6798, doi:10.5194/acp-12-6775-2012, 2012.

Charlson, R. J., Schwartz, S. E., Hales, J. M., Cess, R. D., Coakley, J. A., Hansen, J. E., and Hofmann, D. J.: Climate forcing by anthropogenic aerosols, Science, 255, 423-430, 1992.

Chen, F. and Dudhia, J.: Coupling an advanced land surface hydrology model with the Penn State-NCAR MM5 modeling system. Part I: Model implementation and sensitivity, Mon. Weather Rev., 129, 569-585, doi:10.1175/15200493(2001)129<0569:CAALSH>2.0.Co;2, 2001.

Chou, M.-D. and Suarez, M. J.: A Solar Radiation Parameterization (CLIRAD-SW) for Atmospheric Studies, NASA/TM-1999104606, 15, 48 pp., 1999.

de Villiers, R. A., Ancellet, G., Pelon, J., Quennehen, B., Schwarzenboeck, A., Gayet, J. F., and Law, K. S.: Airborne measurements of aerosol optical properties related to early spring transport of mid-latitude sources into the Arctic, Atmos. Chem. Phys., 10, 5011-5030, doi:10.5194/acp-10-5011-2010, 2010.

Dusek, U., Frank, G. P., Hildebrandt, L., Curtius, J., Schneider, J., Walter, S., Chand, D., Drewnick, F., Hings, S., Jung, D., Borrmann, S., and Andreae, M. O.: Size matters more than chemistry for cloud-nucleating ability of aerosol particles, Science, 312, 1375-1378, 2006.

Emmons, L. K., Walters, S., Hess, P. G., Lamarque, J.-F., Pfister, G. G., Fillmore, D., Granier, C., Guenther, A., Kinnison, D., Laepple, T., Orlando, J., Tie, X., Tyndall, G., Wiedinmyer, C., Baughcum, S. L., and Kloster, S.: Description and evaluation of the Model for Ozone and Related chemical Tracers, version 4 (MOZART-4), Geosci. Model Dev., 3, 43-67, doi:10.5194/gmd3-43-2010, 2010. 
Fahey, K. M. and Pandis, S. N.: Optimizing model performance: variable size resolution in cloud chemistry modelling, Atmos. Environ., 35, 4471-4478, 2001.

Fast, J. D., Gustafson Jr., W. W. I., Easter, R., Zaveri, R. A., Barnard, J. C., Chapman, E. G., Grell, G., and Peckham, S.: Evolution of ozone, particulates, and aerosol direct radiative forcing in the vicinity of Houston using a fully coupled meteorology-chemistry-aerosol model, J. Geophys. Res., 111, D21305, doi:10.1029/2005JD006721, 2006.

Fast, J. D., Gustafson Jr., W. I., Berg, L. K., Shaw, W. J., Pekour, M., Shrivastava, M., Barnard, J. C., Ferrare, R. A., Hostetler, C. A., Hair, J. A., Erickson, M., Jobson, B. T., Flowers, B., Dubey, M. K., Springston, S., Pierce, R. B., Dolislager, L., Pederson, J., and Zaveri, R. A.: Transport and mixing patterns over Central California during the carbonaceous aerosol and radiative effects study (CARES), Atmos. Chem. Phys., 12, 1759-1783, doi:10.5194/acp-12-1759-2012, 2012.

Fisher, J. A., Jacob, D. J., Wang, Q., Bahreini, R., Carouge, C. C., Cubison, M. J., Dibb, J. E., Diehl, T., Jimenez, J. L., Leibensperger, E. M., Lu, Z., Meinders, M. B. J., Pye, H. O. T., Quinn, P. K., Sharma, S., Streets, D. G., van Donkelaar, A., and Yantosca, R. M.: Sources, distribution, and acidity of sulfateammonium aerosol in the Arctic in winter-spring, Atmos. Environ., 45, 7301-7318, doi:10.1016/j.atmosenv.2011.08.030, 2011.

Flamant, C. and Pelon, J.: Atmospheric boundary-layer structure over the Mediterranean during a Tramontane event, Q. J. Roy. Metor. Soc., 122, 1741-1778, 1996.

Flanner, M. G.: Arctic climate sensitivity to local black carbon, J. Geophys. Res., 118, 1-12, doi:10.1002/jgrd.50176, 2013.

Flanner, M. G., Zender, C. S., Randerson, J. T., and Rasch, P. J.: Present-day climate forcing and response from black carbon in snow, J. Geophys. Res., 112, D11202, doi:10.1029/2006JD008003, 2007.

Freitas, S. R., Longo, K. M., Chatfield, R., Latham, D., Silva Dias, M. A. F., Andreae, M. O., Prins, E., Santos, J. C., Gielow, R., and Carvalho Jr., J. A.: Including the sub-grid scale plume rise of vegetation fires in low resolution atmospheric transport models, Atmos. Chem. Phys., 7, 3385-3398, doi:10.5194/acp-7-3385-2007, 2007.

Frossard, A. A., Shaw, P., Russell, L. M., Kroll, J. H., Canagaratna, M. J., Worsnop, D. R., Quinn, P. K., and Bates, T. S.: Springtime Arctic haze contributions of submicron organic particles from European and Asian combustion sources, J. Geophys. Res., 116, D05205, doi:10.1029/2010JD015178, 2011.

Garrett, T. J. and Zhao, C.: Increased Arctic cloud longwave emissivity associated with pollution from mid-latitudes, Nature, 440, 787-789, doi:10.1038/nature04636, 2006.

Garrett, T. J., Brattstrom, S., Sharma, S., Worthy, D. E. J., and Novelli, P.: The role of scavenging in the seasonal transport of black carbon and sulfate to the Arctic, Geophys. Res. Lett., 38, L16805, doi:10.1029/2011g1048221, 2011.

Greenaway, K. R.: Experiences with Arctic flying weather, Royal Meteorol. Soc. Can. Branch, Toronto, Ont., Canada, 1950.

Grell, G. A. and Devenyi, D.: A generalized approach to parameterizing convection combining ensemble and data assimilation techniques, Geoph. Res. Let., 29, 38.1-38.4, doi:10.1029/2002GL015311, 2002.

Grell, G. A., Peckham, S. E., Schmitz, R., McKeen, S. A., Frost, G., Skamarock, W. C., and Eder, B.: Fully coupled "online" chem- istry within the WRF model, Atmos. Environ., 39, 6957-6975, 2005.

Guenther, A., Karl, T., Harley, P., Wiedinmyer, C., Palmer, P. I., and Geron, C.: Estimates of global terrestrial isoprene emissions using MEGAN (Model of Emissions of Gases and Aerosols from Nature), Atmos. Chem. Phys., 6, 3181-3210, doi:10.5194/acp-63181-2006, 2006.

Gustafson, W. I., Qian, Y., and Fast, J. D.: Downscaling aerosols and the impact of neglected subgrid processes on direct aerosol radiative forcing for a representative global climate model grid spacing, J. Geophys. Res., 116, D13303, doi:10.1029/2010JD015480, 2011.

Haylock, M., Hofstra, N., Klein Tank, A., Klok, E., Jones, P., and New, M. A.: European daily high-resolution gridded data set of surface temperature and precipitation for 1950-2006, J. Geophys. Res., 113, D20119, doi:10.1029/2008JD010201, 2008.

Haywood, J. M. and Shine, K. P.: The effect of anthropogenic sulfate and soot aerosol on the clear sky planetary radiation budget, Geophys. Res. Lett., 22, 603-606, 1995.

Hodzic, A., Jimenez, J. L., Madronich, S., Canagaratna, M. R., DeCarlo, P. F., Kleinman, L., and Fast, J.: Modeling organic aerosols in a megacity: potential contribution of semi-volatile and intermediate volatility primary organic compounds to secondary organic aerosol formation, Atmos. Chem. Phys., 10, 5491-5514, doi:10.5194/acp-10-5491-2010, 2010.

Iversen, T. and Joranger, E.: Arctic air pollution and large scale atmospheric flows, Atmos. Environ., 19, 2099-2108, 1985.

Jacobson, M. Z.: Short term effects of controlling fossil fuel soot, biofuel soot and gases, and methane on climate, Arctic ice, and air pollution health, J. Geophys. Res., 115, D14209, doi:10.1029/2009JD013795, 2010.

Janjic, Z. I.: The step-mountain eta coordinate model: further developments of the convection, viscous sublayer, and turbulence closure schemes, Mon. Weather Rev., 122, 927-945, 1994.

Karl, M., Guenther, A., Köble, R., Leip, A., and Seufert, G.: A new European plant-specific emission inventory of biogenic volatile organic compounds for use in atmospheric transport models, Biogeosciences, 6, 1059-1087, doi:10.5194/bg-6-1059-2009, 2009.

Law, K. S., Stohl, A., Quinn, P. K., Brock, C., Burkhart, J., Paris, J.D., Ancellet, G., Singh, H. B., Roiger, A., Schlager, H., Dibb, J., Jacob, D. J., Arnold, S. R., Pelon, J., and Thomas, J. L.: Arctic air pollution: new insights from POLARCAT-IPY, B. Am. Meteorol. Soc., doi:10.1175/BAMS-D-13-00017.1, early online releases, 2014.

Lund Myhre, C., Toledano, C., Myhre, G., Stebel, K., Yttri, K. E., Aaltonen, V., Johnsrud, M., Frioud, M., Cachorro, V., de Frutos, A., Lihavainen, H., Campbell, J. R., Chaikovsky, A. P., Shiobara, M., Welton, E. J., and Tørseth, K.: Regional aerosol optical properties and radiative impact of the extreme smoke event in the European Arctic in spring 2006, Atmos. Chem. Phys., 7, 58995915, doi:10.5194/acp-7-5899-2007, 2007.

Meloni, D., di Sarra, A., Di Iorio, T., and Fiocco, G.: Influence of the vertical profile of Saharan dust on the visible direct radiative forcing, J. Quant. Spectrosc. Ra., 93, 397-413, 2005.

Meng, Z., Dabdub, D., and Seinfeld, J. H.: Chemical coupling between atmospheric ozone and particulate matter, Science, 277, 116-119, 1997. 
Mitchell, J. M.: Visual range in the polar regions with particular reference to the Alaskan Arctic, J. Atmos. Terr. Phys. Spec., Suppl., 1, 195-211, 1957.

Mlawer, E. J., Taubman, S. J., Brown, P. D., Iacono, M. J., and Clough, S. A.: Radiative transfer for inhomogeneous atmospheres: RRTM, a validated correlated- $k$ model for the longwave, J. Geophys. Res., 102, 16663-16682, 1997.

Morrison, H., Thompson, G., and Tatarskii, V.: Impact of cloud microphysics on the development of trailing stratiform precipitation in a simulated squall line: comparison of one and two-moment schemes, Mon. Weather Rev., 137, 991-1007, doi:10.1175/2008mwr2556.1, 2009.

Murrells, T. P., Passant, N. R., Thistlethwaite, G., Wagner, A., Li, Y., Bush, T., Norris, J., Coleman, P. J., Walker, C., Stewart, R. A., Tsagatakis, I., Conolly, C., Brophy, N. C. J., and Okamura, S.: UK Emissions of Air Pollutants 1970 to 2007, AEAa, 2010.

Nicolet, M.: On the molecular scattering in the terrestrial atmosphere: an empirical formula for its calculation in the homosphere, Planet. Space Sci., 32, 1467-1468, 1984.

Pilinis, C., Pandis, S. N., and Seinfeld, J. H.: Sensitivity of direct climate forcing by atmospheric aerosols to aerosol size and composition, J. Geophys. Res., 100, 18739-18754, 1995.

Pueschel, R. F. and Kinne, S. A.: Physical and radiative properties of Arctic atmospheric aerosols, Sci. Total Environ., 161, 811-824, 1995.

Quennehen, B., Schwarzenboeck, A., Schmale, J., Schneider, J., Sodemann, H., Stohl, A., Ancellet, G., Crumeyrolle, S., and Law, K. S.: Physical and chemical properties of pollution aerosol particles transported from North America to Greenland as measured during the POLARCAT summer campaign, Atmos. Chem. Phys., 11, 10947-10963, doi:10.5194/acp-11-10947-2011, 2011.

Quennehen, B., Schwarzenboeck, A., Matsuki, A., Burkhart, J. F., Stohl, A., Ancellet, G., and Law, K. S.: Anthropogenic and forest fire pollution aerosol transported to the Arctic: observations from the POLARCAT-France spring campaign, Atmos. Chem. Phys., 12, 6437-6454, doi:10.5194/acp-12-6437-2012, 2012.

Quinn, P. K., Miller, T. L., Bates, T. S., Ogren, J. A., Andrews, E., and Shaw, G. E.: A three-year record of simultaneously measured aerosol chemical and optical properties at Barrow, Alaska, J. Geophys. Res., 107, 4130, doi:10.1029/2001JD001248, 2002.

Quinn, P. K., Shaw, G., Andrews, E., Dutton, E. G., RuohoAirola, T., and Gong, S. L.: Arctic haze: current trends and knowledge gaps, Tellus B, 59, 99-114, 2007.

Rahn, K. A.: Relative importances of North America and Eurasia sources of arctic aerosol, Atmos. Environ., 15, 1447-1455, doi:10.1016/0004-6981(81)90351-6, 1981.

Rahn, K. A., Borys, R. D., and Shaw, G. E.: Asian source of Arctic haze bands, Nature, 268, 713-715, 1977.

Raut, J.-C. and Chazette, P.: Radiative budget in the presence of multi-layered aerosol structures in the framework of AMMA SOP-0, Atmos. Chem. Phys., 8, 6839-6864, doi:10.5194/acp-86839-2008, 2008.

Schmale, J., Schneider, J., Ancellet, G., Quennehen, B., Stohl, A., Sodemann, H., Burkhart, J. F., Hamburger, T., Arnold, S. R., Schwarzenboeck, A., Borrmann, S., and Law, K. S.: Source identification and airborne chemical characterisation of aerosol pollution from long-range transport over Greenland during POLARCAT summer campaign 2008, Atmos. Chem. Phys., 11, 1009710123, doi:10.5194/acp-11-10097-2011, 2011.
Schwarz, J. P., Spackman, J. R., Gao, R. S., Watts, L. A., Stier, P., Schulz, M., Davis, S. M., Wofsy, S. C., and Fahey, D. W.: Global-scale black carbon profiles observed in the remote atmosphere and compared to models, Geophys. Res. Lett., 37, L18812, doi:10.1029/2010GL044372, 2010.

Schwarzenboeck, A., Heintzenberg, J., and Mertes, M.: Incorporation of aerosol particles between 25 and $850 \mathrm{~nm}$ into cloud element: measurements with a new complementary sampling system, Atmos. Res., 52, 241-260, 2000.

Sessions, W. R., Fuelberg, H. E., Kahn, R. A., and Winker, D. M.: An investigation of methods for injecting emissions from boreal wildfires using WRF-Chem during ARCTAS, Atmos. Chem. Phys., 11, 5719-5744, doi:10.5194/acp-11-5719-2011, 2011.

Shaw, G. E: The Arctic haze phenomenon, B. Am. Meteorol. Soc., 76, 2403-2413, 1995.

Shindell, D. and Faluvegi, G.: Climate response to regional radiative forcing during the twentieth century, Nat. Geosci., 2, 294-300, doi:10.1038/NGEO473, 2009.

Shindell, D. T., Chin, M., Dentener, F., Doherty, R. M., Faluvegi, G., Fiore, A. M., Hess, P., Koch, D. M., MacKenzie, I. A., Sanderson, M. G., Schultz, M. G., Schulz, M., Stevenson, D. S., Teich, H., Textor, C., Wild, O., Bergmann, D. J., Bey, I., Bian, H., Cuvelier, C., Duncan, B. N., Folberth, G., Horowitz, L. W., Jonson, J., Kaminski, J. W., Marmer, E., Park, R., Pringle, K. J., Schroeder, S., Szopa, S., Takemura, T., Zeng, G., Keating, T. J., and Zuber, A.: A multi-model assessment of pollution transport to the Arctic, Atmos. Chem. Phys., 8, 5353-5372, doi:10.5194/acp-8-5353-2008, 2008.

Stohl, A.: Characteristics of atmospheric transport into the Arctic troposphere, J. Geophys. Res., 111, D11306, doi:10.1029/2005JD006888, 2006.

Stohl, A., Forster, C., Frank, A., Seibert, P., and Wotawa, G.: Technical note: The Lagrangian particle dispersion model FLEXPART version 6.2, Atmos. Chem. Phys., 5, 2461-2474, doi:10.5194/acp-5-2461-2005, 2005.

Stohl, A., Berg, T., Burkhart, J. F., Fjæraa, A. M., Forster, C., Herber, A., Hov, Ø., Lunder, C., McMillan, W. W., Oltmans, S., Shiobara, M., Simpson, D., Solberg, S., Stebel, K., Ström, J., Tørseth, K., Treffeisen, R., Virkkunen, K., and Yttri, K. E.: Arctic smoke - record high air pollution levels in the European Arctic due to agricultural fires in Eastern Europe in spring 2006, Atmos. Chem. Phys., 7, 511-534, doi:10.5194/acp-7-511-2007, 2007.

Thomas, J. L., Raut, J.-C., Law, K. S., Marelle, L., Ancellet, G., Ravetta, F., Fast, J. D., Pfister, G., Emmons, L. K., Diskin, G. S., Weinheimer, A., Roiger, A., and Schlager, H.: Pollution transport from North America to Greenland during summer 2008, Atmos. Chem. Phys., 13, 3825-3848, doi:10.5194/acp-13-38252013, 2013.

Toon, O. B. and Ackerman, T. P.: Algorithms for the calculation of scattering by stratified spheres, Appl. Optics, 20, 3657-3660, 1981.

Tuccella, P., Curci, G., Visconti, G., Bessagnet, B., Menut, L., and Park, R. J.: Modeling of gas and aerosol with WRF/Chem over Europe: evaluation and sensitivity study, J. Geophys. Res., 117, D03303, doi:10.1029/2011JD016302, 2012.

Twomey, S.: The influence of pollution on the shortwave albedo of clouds, J. Atmos. Sci., 34, 1149-1152, doi:10.1175/15200469(1977)034<1149:TIOPOT>2.0.CO;2, 1977. 
van der Gon, H. D., Hendriks, C., Kuenen, J., Segers, A., and Visschedijk, A.: Description of Current Temporal Emission Patterns and Sensitivity of Predicted AQ for Temporal Emission Patterns, EU FP7 MACC deliverable report D_D-EMIS_1.3, 2011.

Wang, H., Easter, R. C., Rasch, P. J., Wang, M., Liu, X., Ghan, S. J., Qian, Y., Yoon, J.-H., Ma, P.-L., and Vinoj, V.: Sensitivity of remote aerosol distributions to representation of cloud-aerosol interactions in a global climate model, Geosci. Model Dev., 6, 765-782, doi:10.5194/gmd-6-765-2013, 2013.

Wang, Q., Jacob, D. J., Fisher, J. A., Mao, J., Leibensperger, E. M., Carouge, C. C., Le Sager, P., Kondo, Y., Jimenez, J. L., Cubison, M. J., and Doherty, S. J.: Sources of carbonaceous aerosols and deposited black carbon in the Arctic in winter-spring: implications for radiative forcing, Atmos. Chem. Phys., 11, 1245312473, doi:10.5194/acp-11-12453-2011, 2011.

Warneke, C., Bahreini, R., Brioude, J., Brock, C. A., de Gouw, J. A., Fahey, D. W., Froyd, K. D., Holloway, J. S., Middlebrook, A., Miller, L., Montzka, S., Murphy, D. M., Peischl, J., Ryerson, T. B., Schwarz, J. P., Spackman, J. R., and Veres, P.: Biomass burning in Siberia and Kazakhstan as an important source for haze over the Alaskan Arctic in April 2008, Geophys. Res. Lett., 36, L02813, doi:10.1029/2008GL036194, 2009.

Warneke, C., Froyd, K. D., Brioude, J., Bahreini, R., Brock, C. A., Cozic, J., de Gouw, J. A., Fahey, D. W., Ferrare, R., Holloway, J. S., Middlebrook, A. M., Miller, L., Montzka, S., Schwarz, J. P., Sodemann, H., Spackman, J. R., and Stohl, A.: An important contribution to springtime Arctic aerosol from biomass burning in Russia, Geophys. Res. Lett., 37, L01801, doi:10.1029/2009g1041816, 2010.
Wexler, A. S., Lurmann, F. W., and Seinfeld, J. H.: Modelling urban and regional aerosols - I. Model development, Atmos. Environ., 28, 531-546, 1994.

Wiedinmyer, C., Quayle, B., Geron, C., Belote, A., McKenzie, D., Zhang, X., O’Neill, S., Klos, K., and Wynne, K. K.: Estimating emissions from fires in North America for air quality modelling, Atmos. Environ., 40, 3419-3432, 2006.

Wiedinmyer, C., Akagi, S. K., Yokelson, R. J., Emmons, L. K., AlSaadi, J. A., Orlando, J. J., and Soja, A. J.: The Fire INventory from NCAR (FINN): a high resolution global model to estimate the emissions from open burning, Geosci. Model Dev., 4, 625641, doi:10.5194/gmd-4-625-2011, 2011.

Wild, O., Zhu, X., and Prather, M. J.: Fast-J: accurate simulation of in- and below-cloud photolysis in tropospheric chemical models, J. Atmos. Chem., 37, 245-282, 2000.

Zaveri, R. and Peters, L. K.: A new lumped structure photochemical mechanism for large-scale applications, J. Geophys. Res., 104, 30387-30415, 1999.

Zaveri, R. A., Easter, R. C., Fast, J. D., and Peters, L. K.: Model for Simulating Aerosol Interactions and Chemistry (MOSAIC), J. Geophys. Res., 113, D13204, doi:10.1029/2007JD008792, 2008. 